\title{
Aqueous phase oxidation of bisulfite influenced by nitrate photolysis
}

\author{
Lu Chen ${ }^{\mathrm{a}}$, Lingdong Kong, ${ }^{\mathrm{a}, \mathrm{b}}$, , Songying Tong ${ }^{\mathrm{a}}$, Kejing Yang ${ }^{\mathrm{a}}$, Shengyan Jin ${ }^{\mathrm{a}}$, Chao \\ Wang ${ }^{\mathrm{a}}$, Lin Wang \\ a Department of Environmental Science \& Engineering, Jiangwan Campus, Fudan \\ University, No. 2205 Songhu Road, Shanghai, 200438, China \\ ${ }^{\mathrm{b}}$ Institute of Eco-Chongming, East China Normal University, No.3663 Northern \\ Zhongshan Road, Shanghai 200062, China \\ Correspondence to: Lingdong Kong (ldkong@fudan.edu.cn)
}


1 ABSTRACT: Nitrate aerosol is ubiquitous in the atmosphere, and it can exit in both

solid aerosol particles and fog and cloud droplets. Nitrate in the aqueous and particulate phase can undergo photolysis to produce oxidizing active radicals, which will inevitably affect various atmospheric chemical processes. However, the role of nitrate aerosols in these atmospheric photochemical processes remains unclear. In this study, the effects of nitrate photolysis on the aqueous phase oxidation of bisulfite under different conditions were investigated. Results show that nitrate photolysis can significantly promote the oxidation of bisulfite to sulfate. It is found that $\mathrm{pH}$ plays a significant role in the reaction, and ammonium sulfate has significant impacts on regulating the $\mathrm{pH}$ of solution and the enhancement of sulfate production. We also found an apparent synergism among halogen chemistry, nitrate and its photochemistry and S(IV) aqueous oxidation, especially the oxidation of halide ions by the nitrate photolysis and by the intermediate peroxymonosulfuric acid $\left(\mathrm{HSO}_{5}^{-}\right)$produced by the free radical chain oxidation of S(IV) in acidic solution leads to the coupling of the redox cycle of halogen with the oxidation of bisulfite, which promotes the continuous aqueous oxidation of bisulfite and the formation of sulfate. In addition, it is also found that $\mathrm{O}_{2}$ is of great significance on nitrate photolysis for the conversion of $\mathrm{HSO}_{3}{ }^{-}$, and $\mathrm{H}_{2} \mathrm{O}_{2}$ generation during the nitrate photolysis is verified. These results provide a new insight into the heterogeneous aqueous phase oxidation pathways and mechanisms of $\mathrm{SO}_{2}$ in cloud and fog droplets and haze particles. 


\section{- INTRODUCTION}

The frequent haze events in China in recent years brought about severe impacts on air quality, regional and global climates and human health (Huang et al., 2014; Ji et al., 2014; Zheng et al., 2015b; Zheng et al., 2015a; Li et al., 2014). Secondary aerosols are recognized as a main cause of particulate pollution during haze events (Guo et al., 2014), of which secondary inorganic aerosols produced by the atmospheric conversions of $\mathrm{SO}_{2}$ and $\mathrm{NO}_{\mathrm{x}}$ under adverse meteorological conditions are the predominant components ( $\mathrm{Li}$ et al., 2018b; Sun et al., 2014). Field measurements show that during haze episodes, most of the particles especially the sub-micrometer particles were in the aqueous state owing to the enrichment of aerosol liquid water by the elevated relative humidity (RH) and inorganic fraction in particles (Liu et al., 2017b). As a result, the occurrence of heterogeneous aqueous phase reaction has a marked tendency (Kong et al., 2018), and the role of heterogeneous aqueous phase reaction of $\mathrm{SO}_{2}$ played in secondary sulfate aerosol formation was emphasized (Quan et al., 2015). Generally, the aqueous phase oxidation pathways of $\mathrm{SO}_{2}$ in the cloud and fog droplets include oxidation by $\mathrm{H}_{2} \mathrm{O}_{2}$, oxidation by $\mathrm{O}_{3}$ (Seinfeld and Pandis, 2006), and oxidation by $\mathrm{O}_{2}$ under the catalysis of certain transition metal ions (Ibusuki and Takeuchi, 1987). At $\mathrm{pH} \sim 2-5$, the oxidation by $\mathrm{H}_{2} \mathrm{O}_{2}$ has been considered as the dominant aqueous phase oxidation pathway for sulfate formation (Ye et al., 2018; Shen et al., 2012). This pathway includes the uptake of $\mathrm{SO}_{2}(\mathrm{R} 1$, see in Table 2) and subsequent aqueous phase oxidation of $\mathrm{S}(\mathrm{IV})$ (Alexander et al., 2003). In the $\mathrm{pH}$ range of 2-7, most of the dissolved $\mathrm{SO}_{2}$ will be present as $\mathrm{HSO}_{3}{ }^{-}$in the solution (Hua et al., 2008), and the oxidation of $\mathrm{S}(\mathrm{IV})$ species 
leads to the formation of sulfate (R2). In addition, previous studies proposed that the aqueous-phase oxidation of $\mathrm{S}(\mathrm{IV})$ by $\mathrm{NO}_{2}$ played a dominant role in sulfate production in northern China (Wang, 2016; Cheng et al., 2016), and the acid-base neutralization of $\mathrm{NH}_{3}$ is thought to be the reason of promoting $\mathrm{SO}_{2}$ and $\mathrm{NO}_{2}$ to form corresponding sulfate and nitrate. However, their conclusion was doubted by Liu et al. and Guo et al. (Liu et al., 2017a; Guo et al., 2017), who found that the reaction on the actual fine particles with $\mathrm{pH}$ values of $\sim 4.2$ was too slow to account for sulfate formation. Therefore, some potential oxidation pathways and mechanisms for atmospheric aqueous phase oxidation of S(IV) still remain poorly understood.

Nitrate aerosol constitutes a substantial fraction of fine particles (Tao et al., 2018), and surface nitrate can change the hygroscopicity of original particles (Hoffman et al., 2004), which can be transformed into droplets at a certain RH. Field observation showed that the remarkably enhanced nitrate formation was observed during haze episodes in China (Ji et al., 2014; Tao et al., 2018), which is coincident with the high level of sulfate (Zheng et al., 2015b; Quan et al., 2015), suggesting the impact of nitrate on sulfate formation or the mutual influence between their formation processes in the atmosphere (Du et al., 2019; Kong et al., 2014). Several studies have verified that nitrate does participate in the heterogeneous conversion of $\mathrm{SO}_{2}$. Du et al. (2019) proved that the photolysis of adsorbed nitrate can be coupled with $\mathrm{SO}_{2}$ oxidation and sulfate formation, which is reflected in the consumption of adsorbed nitrate and the formation of adsorbed $\mathrm{N}_{2} \mathrm{O}_{4}$ during the introduction of $\mathrm{SO}_{2}$. Kong et al. (2014) found that nitrate can accelerate the formation of sulfate on hematite and lead to the generation of surface- 
adsorbed $\mathrm{HNO}_{3}$ and gas-phase $\mathrm{N}_{2} \mathrm{O}$ and $\mathrm{HONO}$ under no light. And recently, Gen et al. (2019b) proposed that nitrate photolysis at $250 \mathrm{~nm}$ is the major source of $\mathrm{NO}_{2}$ and $\bullet \mathrm{OH}$ to oxidize dissolved $\mathrm{SO}_{2}$, in which $\bullet \mathrm{OH}$ is believed to be formed when $\mathrm{O}_{2}$ exists, and the reaction of $\cdot \mathrm{OH}$ with dissolved $\mathrm{SO}_{2}$ generates $\mathrm{SO}_{3}{ }^{2-}$, which leads to the chain reaction involving $\mathrm{SO}_{5}^{-}, \mathrm{HSO}_{5}{ }^{-}$and $\mathrm{SO}_{4}{ }^{-}$to produce multiple $\mathrm{SO}_{4}{ }^{2-}$ from each attack of - $\mathrm{OH}$ on dissolved $\mathrm{SO}_{2}$, providing a new insight for the heterogeneous aqueous phase oxidation of $\mathrm{SO}_{2}$ by nitrate photolysis. However, the impacts of various oxidizing species produced and/or initiated by nitrate photolysis under different conditions on the aqueous phase oxidation of $\mathrm{SO}_{2}$ remain unclear. To further reveal the aqueous phase oxidation mechanisms of $\mathrm{SO}_{2}$ in ambient atmosphere, more potential pathways for oxidant generation and S(IV) aqueous phase oxidation, and more ambient factors such as the influence of coexisting substances, are still needed to be explored.

Halide ions (e.g. $\mathrm{Cl}^{-}, \mathrm{Br}^{-}, \mathrm{I}^{-}$) are ubiquitous in the atmosphere via the transport of sea salt aerosols, the emission of fossil fuel combustion and biomass burning (Richards et al., 2011; Cahill et al., 1992; Cheng et al., 2000). The influence of halide ions on the formation of $\mathrm{NO}_{2}$ during the photochemistry of halide-nitrate ion mixtures has been extensively studied (Richards et al., 2011; Richards and Finlayson-Pitts, 2012; Richards-Henderson et al., 2013; Wingen et al., 2008; Custard et al., 2017). For example, Wingen et al. (2008) observed enhanced $\mathrm{NO}_{2}$ production from photolysis of deliquesced nitrate aerosols containing chloride ions, and the reason was suggested that halide ions can draw nitrate ions closer to the interface. Richards et al. (2011) found that irradiated aqueous mixtures of $\mathrm{NaBr} / \mathrm{NaNO}_{3}$ exhibit an enhancement in the rates 
87 of formation of $\mathrm{NO}_{2}$ and $\mathrm{Br}_{2}$ as the bromide mole fraction increased. However, up to

88 now, little attention has been paid to the effect of chemistry of halide ions on sulfate

89 formation under nitrate photolysis.

In this study, the aqueous phase oxidation of bisulfite influenced by nitrate chemistry was investigated under different $\mathrm{pH}$ and irradiation intensity. Compared to earlier works, different mechanisms for the generation of oxidants and the oxidation of S(IV) species were discussed. The $\mathrm{pH}$ was controlled by added ammonium sulfate and ammonium bisulfate because they coexist widely with nitrate in the atmospheric aerosol particles, in which the crucial role of $\mathrm{NH}_{4}{ }^{+}$on sulfate formation was also highlighted. In the meantime, 2-propanol was premixed as inhibitor and $\bullet \mathrm{OH}$ scavenger to examine the roles of $\mathrm{O}_{2}$ and $\bullet \mathrm{OH}$ on the aqueous phase oxidation of bisulfite. Based on this study, the formation of $\mathrm{H}_{2} \mathrm{O}_{2}$ via the recombination of $\bullet \mathrm{OH}$ was verified. And furthermore, the promotion effect of the redox cycling of halogen on the aqueous phase oxidation of bisulfite under nitrate photolysis was investigated.

\section{- MATERIALS AND METHODS}

Materials. Aqueous stock solutions of sodium bisulfite (ACS reagent, SigmaAldrich), ammonium nitrate, ammonium sulfate ( $\geqslant 99.99 \%$ metals basis, Aladdin), ammonium bisulfate ( $\geqslant 99.99 \%$ metals basis, Aladdin), sodium chloride (analytical reagent, Shanghai Qiangshun Chemical Reagent Co., Ltd.), sodium bromide ( $\geqslant 99.99 \%$ metals basis, Aladdin) and sodium iodide ( $\geqslant 99.99 \%$ metals basis, Aladdin) were prepared by dissolving the corresponding salt in Milli-Q water. 2-propanol (HPLC Plus) 

purification.

Photochemical Experiments. Experiments were conducted in a cylindrical quartz

glass cell equipped with an inlet and outlet ports for gas transport and solution sampling, respectively. The top of the cell was sealed with a quartz window (JGS2). Solutions were irradiated from above by simulated sunlight using a Xenon lamp coupled with an optical fiber (CEL-TCX250, Beijing China Education Au-light Co., Ltd.), and a water filter was used in front of the radiation source. The reason is that both solar irradiation and xenon lamp irradiation contain a small fraction $(<5 \%)$ of UV light (Niu et al., 2013). To further explore the reaction mechanisms, irradiation was also conducted by a highpressure mercury lamp (MERC500, NBet Technology Co., Ltd) coupled with a $313 \mathrm{~nm}$ UV optical filter. And $8 \mathrm{~mW} / \mathrm{cm}^{2}$ (measured by an UV light meter, LS125-UVB, Linshang Technology Co., Ltd) was selected as the experimental light intensity after the pre-experiment, which could also achieve the expected results. A thermostatic water bath circulating water through the reactor jacket was used to keep the temperature constant at $25^{\circ} \mathrm{C}$.

Measurements of $\mathrm{SO}_{4}{ }^{2-}$ and $\mathrm{NO}_{\mathrm{x}}$. During the reaction, liquid samples were taken out at given time intervals $(0,20,40, \ldots, 120 \mathrm{~min})$ and $0.1 \mathrm{~mL} 2$-propanol was added to each sample to suppress the continuous oxidation by oxygen in the air during the test process (Braga and Connick, 1982; Alyea and Bäckström, 1929). Then these samples were analyzed by an ion chromatography (940 Professional IC Vario, Metrohm, Switzerland), which was equipped with a separation column of Metrosep A supp 5-250 
and a Metrosep A supp 5 S guard column for anion, and a Metrosep C 6-150 analytical anion eluent to distinguish the peaks of sulfite and sulfate, so as to obtain the accurate content of sulfate in the sample. Detection of $\mathrm{NO}_{\mathrm{x}}$ was conducted in the absence of bisulfite. Nitrogen bubbling was used to help the produced $\mathrm{NO}_{\mathrm{x}}$ escaped from the solution, and then $\mathrm{NO}_{\mathrm{x}}$ was measured using a $\mathrm{NO}-\mathrm{NO}_{2}-\mathrm{NO}_{\mathrm{x}}$ analyzer $(42 \mathrm{i}$, Thermo Scientific, USA).

\section{RESULTS AND DISCUSSION}

Aqueous Oxidation of Bisulfite by Nitrate Photolysis. $\mathrm{NH}_{4} \mathrm{NO}_{3}$ and $\left(\mathrm{NH}_{4}\right)_{2} \mathrm{SO}_{4}$ are the major constituents of atmospheric particulate matter (Sun et al., 2013). Thus, $\mathrm{NH}_{4} \mathrm{NO}_{3}$ was selected as the source of nitrate in this study (Shen et al., 2012). The aqueous oxidation of bisulfite influenced by nitrate photolysis was carried out under different conditions, as shown in Figure 1(a). The reaction with nitrate and light (S1, $\left.13.58 \mu \mathrm{M} \cdot \mathrm{min}^{-1}\right)$ has a higher sulfate formation within $120 \mathrm{~min}$ than that in the dark $(\mathrm{S} 2$, $13.00 \mu \mathrm{M} \cdot \mathrm{min}^{-1}$ ), verifying the promotion of nitrate photolysis on $\mathrm{HSO}_{3}{ }^{-}$oxidation. Considering the insignificant increase of sulfate yield, experiments were conducted under $313 \mathrm{~nm}$ UV light (Figure 1(b)) again to explore the reaction mechanisms. Sulfate formation remarkably enhanced in the presence of nitrate photolysis (S'1, 63.80

$\left.150 \mu \mathrm{M} \cdot \mathrm{min}^{-1}\right)$ compared with the low yield in dark. It may be attributed to the oxidation of

$151 \mathrm{HSO}_{3}{ }^{-}$by various oxidizing species produced by nitrate photolysis, such as $\bullet \mathrm{OH}(\mathrm{Gen}$ et al., 2019b; Mack and Bolton, 1999). $\bullet \mathrm{OH}$ can be produced directly (R3) (Scharko et 
al., 2014), or via indirect pathway induced by nitrate photolysis (R4-10) (Li et al., 2018b; source of $\bullet \mathrm{OH}$, and the photo-formation of $\bullet \mathrm{OH}$ from $\mathrm{HONO}$ and $\mathrm{NO}_{2}{ }^{-}$is $\mathrm{pH}$ dependent (Arakaki et al., 1999). It should be pointed out that the indirect pathways for $\bullet \mathrm{OH}$ formation processes include photoisomerization of nitrate to produce intermediate peroxynitrite $\left(\mathrm{ONOO}^{-}\right)$as well, which can combine with $\mathrm{H}^{+}$to form peroxynitrous acid (HOONO). HOONO can produce $\bullet \mathrm{OH}$ upon decomposition but $\mathrm{ONOO}^{-}$does not, and hence a decrease of $\mathrm{pH}$ would enhance the yield of $\bullet \mathrm{OH}$ photoproduction (Mack and Bolton, 1999), which favors the oxidation of $\mathrm{HSO}_{3}^{-}$. The contribution of $\bullet \mathrm{OH}$ to sulfate formation was discussed later. $\mathrm{NO}_{2}$, another direct product of nitrate photolysis ( $\mathrm{R} 3$ and R4), is also a key factor that leads to $\mathrm{HSO}_{3}{ }^{-}$oxidation. $\mathrm{HSO}_{3}{ }^{-}$is oxidized by $\mathrm{NO}_{2}$ directly (R11) or indirectly (R12) (Li et al., 2018b; Cheng et al., 2016; Guo et al., 2017; Clifton et al., 1988; Gen et al., 2019a). The $\mathrm{NO}_{\mathrm{x}}$ analysis results in Figure 2 show that $\mathrm{NO}_{2}$ is generated rapidly and the yield reached the maximum ( $\left.\sim 54 \mathrm{ppb}\right)$ within $20 \mathrm{~min}$, and then maintained at a relatively stable rate. The simultaneous formation of NO is due to the photolysis of partial $\mathrm{NO}_{2}$ and $\mathrm{HONO}$ (R13 and R14). Additionally, the

171 intermediate products such as nitrite $\left(\mathrm{NO}_{2}{ }^{-}\right)$and nitrous acid (HONO), i.e., $\mathrm{N}(\mathrm{III})$

172 species are also considered as the contributors of aqueous phase $\mathrm{SO}_{2}$ oxidation for

173 sulfate formation as well by previous studies (Gen et al., 2019a; Li et al., 2018b; Kong et al., 2014). And even N(III) species was considered as the main contributors to the 
heterogeneous $\mathrm{SO}_{2}$ aqueous phase oxidation under $300 \mathrm{~nm}$ irradiation, followed by $\mathrm{NO}_{2}$ contribution (Gen et al., 2019a). Therefore, the enhanced sulfate formation in this study is a combined result of the oxidation of bisulfite by various oxidizing species produced by the photolysis of nitrate.

The direct oxidation of $\mathrm{HSO}_{3}^{-}$by $\mathrm{O}_{2}$ cannot be ignored according to $\mathrm{S} 3$ (8.74 $\left.\mu \mathrm{M} \cdot \mathrm{min}^{-1}\right)$. Meanwhile, compared to $\mathrm{S}^{\prime} 1$, the low sulfate formation influenced by nitrate photolysis under oxygen-free condition $\left(\mathrm{S}^{\prime} 4,11.92 \mu \mathrm{M} \cdot \mathrm{min}^{-1}\right)$ indicates the key role of oxygen for the process of nitrate photolysis affecting the conversion of $\mathrm{HSO}_{3}{ }^{-}$. Details were discussed later. And no obvious sulfate generation in the absence of ammonium nitrate and $\mathrm{O}_{2}$ (S5) was observed. The small amount of sulfate increment is attributed to the oxidation of $\mathrm{HSO}_{3}{ }^{-}$by some dissolved $\mathrm{O}_{2}$ in the solution. Another interesting result was found via the comparison between S2 $\left(13.00 \mu \mathrm{M} \cdot \mathrm{min}^{-1}\right)$ and S3 $\left(8.74 \mu \mathrm{M} \cdot \mathrm{min}^{-1}\right)$, that is, nitrate itself can greatly promote the oxidation of bisulfite in the solution under dark condition. This result is consistent with our previous study in which nitrate facilitates the heterogeneous conversion of $\mathrm{SO}_{2}$ on humid hematite particles in the dark (Kong et al., 2014). Furthermore, this result also confirms our previous finding that high-nitrate haze episodes favor the heterogeneous aqueous oxidation of $\mathrm{SO}_{2}$ and the formation of sulfate (Kong et al., 2018). Additionally, stateof-the-art air quality models that rely on sulfate production mechanisms requiring photochemical oxidants fail to predict the high levels of sulfate because the sunlight is usually thought to be weak during haze events (Cheng et al., 2016), this may provide a reasonable explanation for the enhanced conversion of atmospheric $\mathrm{SO}_{2}$ and the 
enhanced formation of secondary sulfate aerosols observed in severe haze episodes with very weak radiation.

Effect of pH on Sulfate Formation. $\mathrm{pH}$ is an important factor affecting the aqueous phase formation of sulfate (Barth et al., 2000), and then its effect on the reaction was investigated. The $\mathrm{pH}$ of initial solution was 4.32 when the concentrations of $\mathrm{NaHSO}_{3}$ and $\mathrm{NH}_{4} \mathrm{NO}_{3}$ were both $30 \mathrm{mM}$. Hence, the formation of sulfate discussed before confirms the occurrence of nitrate photolysis under acidic conditions, as reported by earlier works (Gen et al., 2019b; Scharko et al., 2014; Benedict et al., 2017). Additionally, ammonium sulfate (AS), a salt of a strong acid and a weak base, is the main form of atmospheric sulfate aerosol (Appel et al., 1978), and ammonium bisulfate (ABS) has a stronger acidity, and thus they will inevitably affect the $\mathrm{pH}$ of various aqueous phase system in the atmosphere, such as cloud and fog droplets. Therefore, they were used to further adjust the expected $\mathrm{pH}$ value of the reaction solution in different range in this study. of $\left(\mathrm{NH}_{4}\right)_{2} \mathrm{SO}_{4}, \mathrm{NH}_{4} \mathrm{HSO}_{4}$ and the mixture of $\left(\mathrm{NH}_{4}\right)_{2} \mathrm{SO}_{4}$ and $\mathrm{NH}_{4} \mathrm{HSO}_{4}$, respectively. As can be seen from Figure 3(a), enhanced sulfate formation is observed in all $\left(\mathrm{NH}_{4}\right)_{2} \mathrm{SO}_{4}$-adjusted systems, and more addition of $\left(\mathrm{NH}_{4}\right)_{2} \mathrm{SO}_{4}$ results in lower $\mathrm{pH}$ and more significant sulfate formation. This result not only shows the important role of the

$217 \mathrm{pH}$ in sulfate formation, but also indicates a crucial role of ammonium sulfate in regulating $\mathrm{pH}$ in the enhancement of sulfate formation. This is of great significance for 
understanding the behavior of ammonium sulfate in the atmosphere. On the one hand, the lower $\mathrm{pH}$ favors the formation of $\bullet \mathrm{OH}$ as described by reactions $\mathrm{R} 3-\mathrm{R} 10$. On the other hand, it may because that $\mathrm{NO}_{3}{ }^{-}$under acidic conditions is more easily photolyzed to produce $\cdot \mathrm{OH}$ or HONO (Mack and Bolton, 1999; Bao et al., 2018; Turnipseed et al., 1992). As a result, an increasingly enhanced sulfate formation is achieved as the $\mathrm{pH}$ decreases. However, totally different results are obtained in $\mathrm{NH}_{4} \mathrm{HSO}_{4}$-adjusted systems. The oxidation of bisulfite is greatly suppressed when $\mathrm{pH}<2.08$. One possible explanation is that $\mathrm{HSO}_{3}{ }^{-}$concentration is greatly reduced when $\mathrm{pH}<2.08$ due to the equilibrium of reaction $\mathrm{R} 1$, even though nitrate photolysis under acidic conditions continues, which will lead to the reduction of sulfate formation. This result may suggest that there is an optimum $\mathrm{pH}$ value for sulfate formation. In addition, the middle range of $\mathrm{pH}$ is reached by adding the mixed solution of $\left(\mathrm{NH}_{4}\right)_{2} \mathrm{SO}_{4}$ and $\mathrm{NH}_{4} \mathrm{HSO}_{4}$, and the enhanced sulfate formation is also observed. Sulfate formation as a function of $\mathrm{pH}$ is described in Fig 3(b). As can be seen from it, the $\mathrm{pH}$ for the highest sulfate formation is about 3.86, which is within the $\mathrm{pH}$ range of atmospheric particles. Generally, atmospheric $\mathrm{PM}_{2.5}$ is acidic due to partial neutralization of acidic sulfate and nitrate aerosols under some conditions (Guo et al., 2017; Liu et al., 2017). Liu et al. (2017) found that fine particles were moderately acidic during severe haze episodes in northern the $\mathrm{PM}_{1} \mathrm{pH}$, regardless of ammonia levels, was always acidic, with an average of 4.2 , even for the unusually high $\mathrm{NH}_{3}$ levels found in Beijing $(\mathrm{pH}=4.5)$. Meanwhile, although the sunlight is usually thought to be weak during haze events, field 
observations showed that the photochemical reactivity during the winter or haze episodes is still relatively high (Ye et al., 2018; Tan et al., 2018). Therefore, this result suggests the new aqueous phase oxidation pathways coupled with nitrate photolysis, which may play significant roles in the formation of secondary sulfate and the occurrence and evolution of haze episodes in China.

Additionally, under the same conditions, the comparison of $\mathrm{NaNO}_{3}$ as the source of $\mathrm{NO}_{3}{ }^{-}$for sulfate formation was carried out. Different conclusion from Gen et al. was drew, who believed that the type of cation has little influence on nitrate photolysis (Gen et al., 2019a). As can be seen from Fig 4, sulfate yields with $\mathrm{NaNO}_{3}$ photolysis are both lower than that with $\mathrm{NH}_{4} \mathrm{NO}_{3}$ at the same concentration, for that the hydrolysis of $\mathrm{NH}_{4}^{+}$ may maintain a stable and low $\mathrm{pH}$ of the solution during the process, which is more conducive to the formation of sulfate as described by R3-R10. Meanwhile, the same low sulfate yields by photolysis of $\mathrm{NaNO}_{3}$ and $\mathrm{NH}_{4} \mathrm{NO}_{3}$ at $\mathrm{pH}<2$ verify that too low $\mathrm{pH}$ is unfavorable to sulfate formation again. To further investigate the role of $\mathrm{NH}_{4}^{+}$, the photolysis of $\mathrm{NO}_{3}{ }^{-}$with different $\mathrm{NH}_{4}{ }^{+}$content was conducted within the optimum $\mathrm{pH}$ range. Results in Fig S1 show that sulfate yield increases with the increase of $\mathrm{NH}_{4}^{+}$ content, revealing the significant role of $\mathrm{NH}_{4}{ }^{+}$on the reaction. This may be because that $\mathrm{NH}_{3} \cdot \mathrm{H}_{2} \mathrm{O}_{\text {(aq) }}$ and/or $\mathrm{NH}_{3}(\mathrm{aq})$, which were produced by the hydrolysis of $\mathrm{NH}_{4}^{+}$(RS1), can be oxidized by nitrate photolysis product $\mathrm{NO}_{2}$ (RS2-RS5), and thus the shift of chemical equilibrium enhances the photolysis of nitrate and the generation of $\bullet \mathrm{OH}$. Also, the standard Gibbs energy of formation for the two reactions indicate that the oxidation reactions of $\mathrm{NH}_{3} \cdot \mathrm{H}_{2} \mathrm{O}_{(\mathrm{aq})}$ and $\mathrm{NH}_{3}(\mathrm{aq})$ by $\mathrm{NO}_{2}$ are spontaneous $\left(\Delta_{\mathrm{f}} \mathrm{G}^{\circ}<0\right.$, listed in Text 
S2). Therefore, the generation of $\bullet \mathrm{OH}$ enhances simultaneously, thus leading to the increased sulfate formation. In addition, it is reported that $\mathrm{NH}_{3}$ can promote the hydrolysis of $\mathrm{NO}_{2}$ and induce the explosive growth of $\mathrm{HONO}$ via reaction $\mathrm{R} 6$ by reducing the free energy barrier of the reaction and stabilizing the product state (Li et al., 2018a; Xu et al., 2019). The HONO produced releases $\bullet \mathrm{OH}$ upon photolysis (R10). the crucial role and contribution of ambient widely-existing ammonium sulfate in the formation of sulfate aerosols and photochemical pollution in the atmosphere.

Role of $\mathrm{O}_{2}$ and $\cdot \mathrm{OH}$ in the aqueous oxidation of bisulfite. As mentioned, $\mathrm{O}_{2}$ and - $\mathrm{OH}$ play important roles in the oxidation of $\mathrm{HSO}_{3}{ }^{-}$. We discussed it further here. It is reported that alcohols can be used as inhibitors of sulfite and bisulfite oxidation (Braga and Connick, 1982; Alyea and Bäckström, 1929). Braga and Connick found that the oxidation of $\mathrm{S}(\mathrm{IV})$ by $\mathrm{O}_{2}$ is a chain reaction, and alcohols can inhibit the reaction by chain termination (Braga and Connick, 1982), but Alyea and Bäckström claimed that the oxidation of the S(IV) induces the oxidation of alcohols and the alcohols can be easily oxidized to aldehydes and ketones (Alyea and Bäckström, 1929). In addition, in the presence of 2-propanol, $\bullet \mathrm{OH}$ reacts primarily with 2-propanol $\left(\mathrm{k}=1.9 \times 10^{9} \mathrm{M}^{-1} \mathrm{~s}^{-1}\right)$ through $\alpha$-hydrogen abstraction generating 1-hydroxy-1-methylethyl radical, while at lower concentrations of 2-propanol, the scavenging reaction of $\bullet \mathrm{OH}$ with $\mathrm{H}_{2} \mathrm{O}_{2}(\mathrm{R} 15)$ become competitive (Hislop and Bolton, 1999). The formation of $\mathrm{H}_{2} \mathrm{O}_{2}$ in the reaction systems will be discussed later. Therefore, in this study, 2-propanol was added to 

presented in Fig 5. As can be seen from Fig.5, a slight reduction of sulfate formation after the addition of 2-propanol was observed in the dark, indicating the suppression of 2-propanol on the oxidation of $\mathrm{HSO}_{3}{ }^{-}$by $\mathrm{O}_{2}$ because that 2-propanol can inhibit the chain reaction between $\mathrm{HSO}_{3}{ }^{-}$and $\mathrm{O}_{2}$ by chain termination (Braga and Connick, 1982), or be easily oxidized by $\mathrm{O}_{2}$ induced by the oxidation of $\mathrm{HSO}_{3}^{-}$(Alyea and Bäckström, 1929), as mentioned before. The inconspicuous inhibition showed that $\mathrm{O}_{2}$ oxidation is not the main direct contributor on the aqueous phase oxidation of bisulfite in the presence of nitrate.

However, as proved before, $\mathrm{O}_{2}$ is of great significance on nitrate photolysis for the conversion of $\mathrm{HSO}_{3}{ }^{-}$. On the one hand, the inhibition of 2-propanol on sulfate yield in the presence and absence of $\mathrm{O}_{2}$ under light were similar (Figure 5), demonstrating that $\mathrm{O}_{2}$ has little effect on the generation of $\bullet \mathrm{OH}$ by nitrate photolysis. This is definitely distinct with previous report by Gen et al. (2019b), who found that $\bullet \mathrm{OH}$ is generated in the presence of $\mathrm{O}_{2}$. Furthermore, they claimed that the contribution of $\bullet \mathrm{OH}$ pathway on the oxidation of dissolved $\mathrm{SO}_{2}$ was almost absent $(<1 \%)$ under nitrate photolysis at 300 nm (Gen et al., 2019a). In our study, $8.59 \%$ and $25.02 \%$ of sulfate formation in the presence and absence of $\mathrm{O}_{2}$ respectively under $313 \mathrm{~nm}$ irradiation were owing to the -OH oxidation, which is not obviously negligible. The quantum yield of $\bullet \mathrm{OH}(\Phi \cdot \mathrm{OH})$ was measured further (Text S4). The calculated $\Phi \cdot \bullet_{\mathrm{OH}}$ in Table 1 shows that lower $\mathrm{pH}$ facilitates the generation of $\bullet \mathrm{OH}$ during nitrate photolysis, verifying the points discussed before again. However, considering that the $\bullet \mathrm{OH}$ would be recombined to 
308 is not the completely accurate one.

In addition, it is reasonably inferred that $\mathrm{O}_{3}$ was generated during nitrate photolysis and became an important contributor for sulfate formation. As is known to all that in aqueous solution $\mathrm{O}\left({ }^{3} \mathrm{P}\right)$ (one of the products of nitrate photolysis, R5) can react with molecular oxygen to form ozone similar to the gas phase (R16) (Herrmann, 2007). Therefore, it is expected that $\mathrm{HSO}_{3}{ }^{-}$will be oxidized by $\mathrm{O}_{3}$, but this still needs further study.

\section{Generation of hydrogen peroxide during the photolysis process}

Previous studies haven't detected $\mathrm{H}_{2} \mathrm{O}_{2}$ during steady-state irradiation of $\mathrm{NO}_{2}{ }^{-}$and $\mathrm{NO}_{3}{ }^{-}$solutions at $\lambda>200 \mathrm{~nm}$ (Daniels et al., 1968; Shuali et al., 1969; Mark et al., 1996), but Wagner et al. once found $\mathrm{H}_{2} \mathrm{O}_{2}$ formation in flash photolysis of nitrate ions in acidic aqueous solution (Wagner et al., 1980). However, Mack et al. thought that the combination reaction between two $\cdot \mathrm{OH}$ produced by nitrate photolysis is highly unlikely due to the very low concentration and short lifetime of $\bullet \mathrm{OH}$, and they attributed the formation of $\mathrm{H}_{2} \mathrm{O}_{2}$ observed by Wagner et al. to the $\mathrm{H}_{2} \mathrm{O}$ photolysis at $\lambda>180 \mathrm{~nm}$ (Mack and Bolton, 1999). However, Yabushita et al. (2008) once again found that the produced $\bullet \mathrm{OH}$ by the photolysis of nitrate originated from the adsorption of nitric acid can recombine to form $\mathrm{H}_{2} \mathrm{O}_{2}$ under low-temperature ice conditions.

$327 \quad \mathrm{H}_{2} \mathrm{O}_{2}$ generation during the photochemical process of nitrate was verified in this study. $\mathrm{H}_{2} \mathrm{O}_{2}$ was measured by titanium (III) sulfate spectrophotometry and the results 
are depicted in Fig $\mathrm{S} 2$. The production of $\mathrm{H}_{2} \mathrm{O}_{2}$ shows a trend of increasing first and then decreasing, which is due to the fact that $\mathrm{H}_{2} \mathrm{O}_{2}$ is photodegraded as its formation. Considering the contributions of $\mathrm{NH}_{4}{ }^{+}$and $\mathrm{pH}$, and the absence of precursor of hydroperoxyl radical $\left(\mathrm{HO}_{2}\right)$ in our reaction system, we can speculate that the formation of $\mathrm{H}_{2} \mathrm{O}_{2}$ is owing to the recombination of $\bullet \mathrm{OH}$ originated from nitrate photolysis and it may make an important contribution to $\mathrm{HSO}_{3}{ }^{-}$oxidation and sulfate formation. When

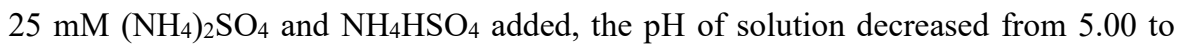
4.63 and 0.97 respectively, as a result, $\mathrm{H}_{2} \mathrm{O}_{2}$ formation is found to be remarkably $\mathrm{pH}$ dependent. The formation of $\mathrm{H}_{2} \mathrm{O}_{2}$ displayed a higher efficiency at a lower $\mathrm{pH}$, which indicates that lower $\mathrm{pH}$ favors the photolysis of nitrate to generate $\bullet \mathrm{OH}$ and the formation of $\mathrm{H}_{2} \mathrm{O}_{2}$. These may reveal the new formation pathways to the source of $\mathrm{H}_{2} \mathrm{O}_{2}$ in cloud, fogs and liquid haze particles, which may be important for the conversion of atmospheric $\mathrm{SO}_{2}$ and the formation of atmospheric sulfate, as well as the occurrence and evolution of haze events. Such aspects need to be further explored in future. or haze episodes and facilitates the production of secondary pollutants (Lu et al., 2019). In the late period of haze events with weak solar radiation, significant increase of sulfate and nitrate was observed (Quan et al., 2015). In order to reveal the impact of the solar

\section{Effect of light intensity on aqueous phase formation of sulfate.}

Although sunlight is dimmed by ambient PM during haze events, it is not completely absent (Xia et al., 2018), and the active photochemistry is also found during the winter radiation on sulfate formation through the aqueous phase pathways we mentioned 
351 above, we carried out experiments under a higher light intensity. As shown in Fig S5, a

352 higher light intensity more favors sulfate formation than that under $8 \mathrm{~mW} / \mathrm{cm}^{2}$

353 irradiation.

Role of Halide Ions in Aqueous Phase Oxidation of Bisulfite. Field observations and atmospheric particles due to the transport of sea salt aerosols, the emission of fossil fuel combustion and biomass burning. Our previous study verified that high-nitrate haze episodes occurred in Shanghai (a coastal mega-city) favored heterogeneous aqueous oxidation of $\mathrm{SO}_{2}$ (Kong et al., 2018). However, little is known about the role of halide ions in the heterogeneous aqueous oxidation of $\mathrm{SO}_{2}$ and the formation of sulfate. Therefore, the role of halide ions in the aqueous phase oxidation of $\mathrm{HSO}_{3}{ }^{-}$under nitrate photolysis was further investigated. Results in Fig 7(a) show that sulfate formation is evidently enhanced in the presence of halide ions $\mathrm{X}^{-}$or $\mathrm{Y}^{-}(\mathrm{X}, \mathrm{Y}$ : $\mathrm{Cl}, \mathrm{Br}$ and I), indicating the promotion effect of halide ions on aqueous phase oxidation of bisulfite in the presence of nitrate and light. owing to halide photochemistry and the redox cycle of halogen was proposed for the first time. Firstly, direct photolysis of $\mathrm{X}^{-}$generates $\mathrm{X}^{*}$, followed by the rapid reaction of $\mathrm{X}^{*}$ with halide ion $\mathrm{X}^{-}$(or $\mathrm{Y}^{-}$) to form $\mathrm{X}_{2}{ }^{--}$(or $\mathrm{XY}^{*-}$ ) as reaction $\mathrm{R} 17$ and $\mathrm{R} 18$ (Zhang and Parker, 2018). Secondly, halide ions can be oxidized by nonhalogen radicals from nitrate photolysis and the free radical chain oxidation of S(IV) [e.g. • OH (R19); sulfate 
radical, $\left.\mathrm{SO}_{4}{ }^{--}(\mathrm{R} 21)\right]$ to generate halogen radicals, and halogen radicals are present at

374 higher concentrations relative to $\bullet \mathrm{OH}$ in more acidic solutions (Zhang and Parker, 2018),

375 as indicated by reaction R19-R22. Additionally, peroxymonosulfuric acid $\left(\mathrm{HSO}_{5}{ }^{-}\right)$

produced by the free radical chain oxidation of S(IV) is known to react with halide ions generates $\mathrm{X}^{*}$ and $\bullet \mathrm{OH}$ (reaction $\mathrm{R} 24$ ). Nonradical halogen oxidant products $\mathrm{X}_{2}$ and HOX can also be formed from rapid reactions R25-R29 (Zhang and Parker, 2018). And, the reaction of $\mathrm{HOBr}$ with $\mathrm{Br}^{-}$(or $\mathrm{Cl}^{-}$) can also lead to the production of $\mathrm{Br}_{2}$ (or $\mathrm{BrCl}$ ), as described by R30 and R31 (Mozurkewich, 1995; Vogt et al., 1996). Moreover, •OH can oxidize both $\mathrm{Cl}^{-}$and $\mathrm{Br}^{-}$to form photochemically active halogen molecules such as $\mathrm{Br}_{2}, \mathrm{BrCl}$ and $\mathrm{Cl}_{2}$ (R32-R34) (Alexander et al., 2003; Richards and Finlayson-Pitts, 2012; Richards-Henderson et al., 2013). In addition, $\mathrm{Br}^{-}$can be oxidized to $\mathrm{Br}_{2}$ by nitrate under acidic conditions in the dark (R35), and the formed HONO further oxidizes $\mathrm{Br}^{-}$ (Richards-Henderson et al., 2013). These nonradical halogen oxidant products may contribute to subsequent oxidation of $\mathrm{HSO}_{3}{ }^{-}$(R36, R37), e.g., rapid $\mathrm{S}(\mathrm{IV})$ oxidation by $\mathrm{HOCl}$ and $\mathrm{HOBr}$ (R38, R39) (Richards and Finlayson-Pitts, 2012; Vogt et al., 1996). It should be noted that althrough the direct photolysis of halide ions exists, this pathway may play a small role in our study because the used xenon lamp emits very few specific wavelengths for the reaction.

Therefore, in this study, compared to that in the absence of halide ions, extra oxidations caused by the introduction of halide ions significantly promote the conversion of $\mathrm{HSO}_{3}^{-}$and the formation of sulfate, showing an apparent synergism 
among halogen chemistry, nitrate photolysis and S(IV) aqueous oxidation. Herein, it

396 should point out that the redox cycle of halogen for the oxidation of $\mathrm{HSO}_{3}{ }^{-}$under nitrate photolysis exists. That is, the oxidants $\mathrm{HOX}$ and $\mathrm{X}_{2}$ produced by the oxidation of halide ions react with bisulfite to generate sulfate as well as to regenerate halide ions, thus forming a redox cycle of halogen to achieve the continuous oxidation conversion of bisulfite. Halide ions act as catalysts in the cyclic reactions. Furthermore, Fig 7(a) also shows that the sulfate yields of the three groups with the addition of $\mathrm{Cl}^{-}, \mathrm{Br}^{-}$and $\mathrm{I}^{-}$ exhibit an increasing tendency, especially the one with added $\mathrm{I}^{-}$, which is much higher than that of the $\mathrm{Cl}^{-}$and $\mathrm{Br}^{-}$. On the one hand, $\mathrm{pH}$ plays a key role. The $\mathrm{pH}$ of bulk solution with addition of $\mathrm{Cl}^{-}, \mathrm{Br}^{-}$and $\mathrm{I}^{-}$are 4.42, 4.20 and 3.60, respectively. As depicted in Fig 3(b) the lower $\mathrm{pH}$ of the three favors sulfate formation. On the other hand, sulfate

406 yields present an order of $\mathrm{Cl}^{-}$-added system $<\mathrm{Br}^{-}$-added system $<\mathrm{I}^{-}$-added system, which is consistent with their reducibility. Compared with $\mathrm{Cl}_{2} / \mathrm{Cl}^{-}$and $\mathrm{Br}_{2} / \mathrm{Br}^{-}$redox cycles, the formed $\mathrm{I}_{2}$ has stronger oxidizability, and $\mathrm{I}^{-}$has stronger reducibility, and thus it is easier to form $\mathrm{I}_{2} / \mathrm{I}^{-}$(or $\mathrm{I}_{3}^{-} / \mathrm{I}^{-}$) redox cycle in our reaction system, resulting in a higher sulfate yield. In addition, it is noteworthy that the added halide ions promote the aqueous phase oxidation of $\mathrm{HSO}_{3}{ }^{-}$in the dark as well, as can be seen from Fig 7(b). But the sulfate yield of dark reaction with different $\mathrm{X}^{-}$is lower than that with light. This result indicates the simultaneous contributions of the decreased $\mathrm{pH}$ and the redox cycle of halogen originated from the reaction R22, R23 and R35 and the aqueous phase

415 oxidation of $\mathrm{HSO}_{3}{ }^{-}$in the absence of light. Similarly, the autocatalytic reaction of this system is achieved as well in the dark. 
418 photochemistry as well as $\mathrm{HSO}_{5}^{-}$will be coupled with the aqueous phase oxidation process of $\mathrm{SO}_{2}$ to greatly promote the formation of sulfate, both under the light and dark conditions, which is of great significance to understand the impacts of sea salt aerosol in coastal areas of China and the halide ions from coal combustion in northern areas of episodes or air pollution in China. Additionally, the transport of biomass burning can induce air pollution and haze episodes in the receptor areas by the significantly enhanced formation of secondary sulfate and nitrate aerosols (Du et al., 2011; Tong et al., 2020). The interactions between the plume of biomass burning and local pollutants are often used to explain the enhanced secondary aerosol formation, but the real reason remain unclear. Therefore, the role of halogen chemistry we studied may provide a reasonable explanation for the occurrence of haze episodes induced by biomass burning. These lay a foundation for us to extend the relevant research to the formation of atmospheric SOA and organic halides in the future.

\section{CONLUSIONS AND ATMOSPHERIC IMPLICATIONS}

The effects of nitrate photolysis on the aqueous phase oxidation of bisulfite under different conditions have been investigated. A combining contribution of various oxidizing species $\left(\bullet \mathrm{OH}, \mathrm{NO}_{2}, \mathrm{NO}_{2}^{-}\right.$and $\mathrm{HONO}$, etc.) produced via the photolysis of

437 nitrate achieves the enhanced oxidation of bisulfite and the enhanced sulfate formation. pH plays a significant role in bisulfite oxidation and sulfate formation. The highest 
439 sulfate formation occurs in the range of moderate acidity, about 3.86, which is within 440 the $\mathrm{pH}$ range of atmospheric particles. Furthermore, $\mathrm{NH}_{4}^{+}$promotes the generation of $441 \cdot \mathrm{OH}$ and thus enhances the formation of sulfate, which is attributed to the oxidation of $442 \mathrm{NH}_{4}{ }^{+}$hydrolysis products $\mathrm{NH}_{3} \cdot \mathrm{H}_{2} \mathrm{O}_{\text {(aq) }}$ and $\mathrm{NH}_{3(\mathrm{aq})}$ by $\mathrm{NO}_{2}$, and the promotion role of $443 \mathrm{NH}_{4}^{+}$hydrolysis products in the hydrolysis of $\mathrm{NO}_{2}$ to form $\mathrm{HONO}$. Additionally, $\mathrm{O}_{2}$ remarkably facilitates nitrate photolysis for the conversion of $\mathrm{HSO}_{3}{ }^{-}$. And $\mathrm{H}_{2} \mathrm{O}_{2}$ can be generated via the recombination of $\bullet \mathrm{OH}$ from nitrate photolysis. More importantly, the redox cycle of halogen coupled with S(IV) oxidation significantly promote the conversion of $\mathrm{HSO}_{3}{ }^{-}$and the formation of sulfate under nitrate photolysis or in acidic nitrate solution in the dark, showing the apparent synergism among halogen chemistry, nitrate chemistry and S(IV) aqueous oxidation. Our study verifies that S(IV) oxidation can be coupled not only with nitrate and its photochemistry, but also with the redox cycle of halogen, which greatly promotes the formation of sulfate.

Results from this study have important atmospheric implications. Firstly, in recent years in China, photochemical pollution and haze episodes have occurred more frequently and the haze episodes with high nitrate level are increasingly apparent. Due to the relatively high $\mathrm{RH}$ and high concentrations of particulate nitrate, the aerosol is mostly in the aqueous phase during haze episodes (Liu et al., 2017b; Kong et al., 2018; Lu et al., 2019). Meanwhile, sunlight is not completely absent during haze episodes (Ye et al., 2018; Xia et al., 2018), and the active photochemistry is also found during the

459 winter or haze episodes and facilitates the production of secondary pollutants (Lu et al., 2019). Therefore, the enhanced aqueous phase oxidation of bisulfite and the enhanced 
461 formation of sulfate under the coupling with nitrate photolysis or in the nitrate solution

462 under dark condition may occur in the haze episodes and promote the occurrence and evolution of haze episodes in China. In the meantime, the important roles of ammonium sulfate in regulating the $\mathrm{pH}$ of solution and the enhancement of sulfate production will also be reflected.

Secondly, nitrate aerosol is ubiquitous in the atmosphere, and it will inevitably mix with halide ions $\left(\mathrm{X}^{-}=\mathrm{Cl}^{-}, \mathrm{Br}^{-}, \mathrm{I}^{-}\right)$from sea salt particles, coal combustion and biomass burning, especially over the coastal areas and the northern areas of China. The typical haze areas in China include Beijing-Tianjin-Hebei area, Yangtze River Delta area and Pearl River Delta area, the three coastal areas in nature, which may suggest the potential roles of halide ions in the occurrence and evolution of hazes. Therefore, the reactions such as those reported here may occur in aqueous phase aerosols (e.g. fog and cloud droplets) or aerosol particles with water film, and the formation of $\mathrm{X} \cdot \mathrm{NO}_{2}, \mathrm{HOX}, \mathrm{X}_{2}$, $\mathrm{XY}$ or the $\mathrm{X}_{2} / \mathrm{X}^{-}$redox cycle will further enhance the conversion of $\mathrm{SO}_{2}$ and/or oxidation of organic gaseous precursors, thus promoting the occurrence and evolution of air pollution or haze. Our study highlights the roles of halide ions in the formation of secondary aerosols and air pollution. Meanwhile, the formed $\mathrm{X} \cdot \mathrm{X}_{2}$ or $\mathrm{XY}$ may be liberated from the aqueous phase particles or the particles with water film into the air, and thus they will affect the tropospheric $\mathrm{O}_{3}$ level.

480 Finally, secondary organic aerosol (SOA) is also an important component of 481 atmospheric aerosols, and it has attracted much attention all the time. Our investigation provides a case study on the formation of secondary inorganic aerosols, which can be 
483 extended to the study on the influences of nitrate photochemistry and the coupled redox

484 cycle of halogen on the formation of SOA, such as the hydroxylation and halogenation

485 of organic substrates, etc.

- ASSOCIATED CONTENT

487 Supporting Information

\section{- AUTHOR INFORMATION}

\section{Corresponding Author}

490 *E-mail: ldkong@fudan.edu.cn

\section{ORCID}

\section{$492 \quad$ Notes}

493 The authors declare no competing financial interest.

494

495

496

497

498

499

500

501

502

503

504

\section{- AUTHOR CONTRIBUTION}

Lingdong Kong, as a tutor, guided and provided suggestions in the whole research process. Lu Chen undertook the main experiment and prepared the manuscript with contributions from all co-authors. Songying Tong and Kejing Yang provided guidance on experimental instruments and their operation methods. Shengyan Jin and Chao Wang carried out some basic experiments. And Lin Wang provided a part of financial support on instruments and materials.

\section{ACKNOWLEDGEMENTS}

This study was supported by the National Natural Science Foundation of China (Grant Nos. 21777027 and 21976032) and the National Key R \& D Program of China (2017YFC0209505). 


\section{REFERENCES}

Alexander, L., Gaspar, D. J., Weihong, W., Hunt, S. W., Cowin, J. P., Colson, S. D., and Finlayson-Pitts, B. J.: Reactions at interfaces as a source of sulfate formation in sea-salt particles, Science, 301, 340344, https://doi.org/10.1126/science.1085374, 2003.

Alyea, H. N., and Bäckström, H. L. J.: The inhibitive action of alcohols on the oxidation of sodium sulfite, J. Am. Chem. Soc, 51, 90-109, https://doi.org/10.1021/ja01376a011, 1929.

Appel, B. R., Kothny, E. L., Hoffer, E. M., Hidy, G. M., and Wesolowski, J. J.: Sulfate and nitrate data from the California Aerosol Characterization Experiment (ACHEX), Environ. Sci. Technol, 12, 418-425, https://doi.org/10.1021/es60140a005, 1978.

Arakaki, T., Miyake, T., Hirakawa, T., and Sakugawa, H.: pH dependent photoformation of hydroxyl radical and absorbance of aqueous-phase $\mathrm{N}(\mathrm{III})\left(\mathrm{HNO}_{2}\right.$ and $\left.\mathrm{NO}_{2}{ }^{-}\right)$, Environ. Sci. Technol, 33, 2561 2565, https://doi.org/10.1021/es980762i, 1999.

Bao, F., Li, M., Zhang, Y., Chen, C., and Zhao, J.: Photochemical aging of Beijing urban PM2.5: HONO production, Environ. Sci. Technol, 52, 6309-6316, https://doi.org/10.1021/acs.est.8b00538, 2018.

Barth, M. C., Rasch, P. J., Kiehl, J. T., Benkovitz, C. M., and Schwartz, S. E.: Sulfur chemistry in the National Center for Atmospheric Research Community Climate Model: Description, evaluation, features, and sensitivity to aqueous chemistry, J. Geophys. Res. Atmos, 105, 1387-1415, http://dx.doi.org/10.1029/1999JD900773, 2000.

Benedict, K. B., McFall, A. S., and Anastasio, C.: Quantum yield of nitrite from the photolysis of aqueous nitrate above $300 \mathrm{~nm}$, Environ. Sci. Technol, 51, 4387-4395, https://doi.org/10.1021/acs.est.6b06370, 2017.

Braga, T. G., and Connick, R. E.: Kinetics of the oxidation of bisulfite ion by oxygen, in: Flue Gas Desulfurization, ACS Symposium Series, 188, American Chemical Society, 153-171, http://dx.doi.org/10.1021/bk-1982-0188.ch008, 1982.

Cahill, T. A., Wilkinson, K., and Schnell, R.: Composition analyses of size-resolved aerosol samples taken from aircraft downwind of Kuwait, spring 1991, J. Geophys. Res. Atmos, 97, 14513-14520, http://dx.doi.org/10.1029/92JD01373, 1992.

Cheng, Y., Zheng, G., Wei, C., Mu, Q., Zheng, B., Wang, Z., Gao, M., Zhang, Q., He, K., Carmichael, G., Pöschl, U., and Su, H.: Reactive nitrogen chemistry in aerosol water as a source of sulfate during haze events in China, Sci Adv, 2, http://dx.doi.org/e1601530-e1601530, 10.1126/sciadv.1601530, 2016.

Cheng, Z. L., Chan, L. W. T., Cheng, K. K., and Lam, K. S.: Chemical characteristics of aerosols at coastal station in Hong Kong. I. Seasonal variation of major ions, halogens and mineral dusts between 1995 and 1996, Atmos. Environ, 34, 2771-2783, http://dx.doi.org/10.1016/S13522310(99)00343-X, 2000.

Clifton, C. L., Altstein, N., and Huie, R. E.: Rate constant for the reaction of nitrogen dioxide with sulfur(IV) over the $\mathrm{pH}$ range 5.3-13, Environ. Sci. Technol, 22, 586-589, http://dx.doi.org/10.1021/es00170a018, 1988.

Custard, K. D., Raso, A. R. W., Shepson, P. B., Staebler, R. M., and Pratt, K. A.: Production and release of molecular bromine and chlorine from the arctic coastal snowpack, ACS. Earth. Space. Chem, 1, 142-151, http://dx.doi.org/10.1021/acsearthspacechem.7b00014, 2017.

Daniels, M., Meyers, R. V., and Belardo, E. V.: Photochemistry of the aqueous nitrate system. I. Excitation in the 300-m.mu. band, J. Phys. Chem, 72, https://doi.org/10.1021/j100848a002, 1968. 
Du, C., Kong, L., Zhanzakova, A., Tong, S., Yang, X., Wang, L., Fu, H., Cheng, T., Chen, J., and Zhang, S.: Impact of adsorbed nitrate on the heterogeneous conversion of $\mathrm{SO}_{2}$ on alpha- $\mathrm{Fe}_{2} \mathrm{O}_{3}$ in the absence and presence of simulated solar irradiation, Sci. Total. Environ, 649, 1393-1402, http://dx.doi.org/10.1016/j.scitotenv.2018.08.295, 2019.

Du, H., Kong, L., Cheng, T., Chen, J., Du, J., Li, L., Xia, X., Leng, C., and Huang, G.: Insights into summertime haze pollution events over Shanghai based on online water-soluble ionic composition of aerosols, Atmos. Environ, 45, 5131-5137, http://dx.doi.org/10.1016/j.atmosenv.2011.06.027, 2011.

Dubowski, Y., Colussi, A. J., and Hoffmann, M. R.: Nitrogen dioxide release in the $302 \mathrm{~nm}$ band photolysis of spray-frozen aqueous nitrate solutions. Atmospheric implications, J. Phys. Chem. A, 105, 4928-4932, http://dx.doi.org/10.1021/jp0042009, 2001.

Gen, M., Zhang, R., Huang, D. D., Li, Y., and Chan, C. K.: Heterogeneous oxidation of $\mathrm{SO}_{2}$ in sulfate production during nitrate photolysis at $300 \mathrm{~nm}$ : Effect of $\mathrm{pH}$, relative humidity, irradiation intensity, and the presence of organic compounds, Environ. Sci. Technol, 53, 8757-8766, http://dx.doi.org/10.1021/acs.est.9b01623, 2019a.

Gen, M., Zhang, R., Huang, D. D., Li, Y., and Chan, C. K.: Heterogeneous $\mathrm{SO}_{2}$ oxidation in sulfate formation by photolysis of particulate nitrate, Environ. Sci. Technol. Lett, 6, 86-91, http://dx.doi.org/10.1021/acs.estlett.8b00681, 2019b.

Gligorovski, S., Strekowski, R., Barbati, S., and Vione, D. J. C. R.: Environmental implications of hydroxyl radicals (•OH), Chem. Rev, 115, 13051-13092, http://dx.doi.org/10.1021/cr500310b, 2015.

Guo, H., Weber, R. J., and Nenes, A.: High levels of ammonia do not raise fine particle pH sufficiently to yield nitrogen oxide-dominated sulfate production, Sci. Rep, 7, 12109, http://dx.doi.org/10.1038/s41598-017-11704-0, 2017.

Guo, S., Hu, M., Levy Zamora, M., Peng, J., Shang, D., Zheng, J., Du, Z., Wu, Z., Shao, M., Zeng, L., Molina, M., and Zhang, R.: Elucidating severe urban haze formation in China, P. Natl. Acad. Sci. USA, http://dx.doi.org/111, 10.1073/pnas.1419604111, 2014.

Herrmann, $\mathrm{H} .:$ On the photolysis of simple anions and neutral molecules as sources of $\mathrm{O}^{-} / \mathrm{OH}, \mathrm{SO}_{\mathrm{x}}{ }^{-}$and $\mathrm{Cl}$ in aqueous solution, Phys. Chem. Chem. Phys, 9, 3935-3964, http://dx.doi.org/10.1039/b618565g, 2007.

Hislop, K. A., and Bolton, J. R.: The photochemical generation of hydroxyl radicals in the UVvis/Ferrioxalate $/ \mathrm{H}_{2} \mathrm{O}_{2} \quad$ system, Environ. Sci. Technol, 33, 3119-3126, http://dx.doi.org/10.1021/es9810134, 1999.

Hoffman, R. C., Laskin, A., and Finlayson-Pitts, B. J.: Sodium nitrate particles: physical and chemical properties during hydration and dehydration, and implications for aged sea salt aerosols, J. Aerosol. Sci, 35, 869-887, http://dx.doi.org/10.1016/j.jaerosci.2004.02.003, 2004.

Hua, W., Chen, Z., Jie, C., Kondo, Y., Hofzumahaus, A., Takegawa, N., Lu, K., Miyazaki, Y., Kita, K., and Wang, H.: Atmospheric hydrogen peroxide and organic hydroperoxides during PRIDE-PRD'06, China: their concentration, formation mechanism and contribution to secondary aerosols, Atmos. Chem. Phys, 8, 6755-6773, https://doi.org/10.5194/acp-8-6755-2008, 2008.

Huang, R. J., Zhang, Y., Bozzetti, C., Ho, K. F., Cao, J. J., Han, Y., Daellenbach, K. R., Slowik, J. G., Platt, S. M., Canonaco, F., Zotter, P., Wolf, R., Pieber, S. M., Bruns, E. A., Crippa, M., Ciarelli, G., Piazzalunga, A., Schwikowski, M., Abbaszade, G., Schnelle-Kreis, J., Zimmermann, R., An, Z., Szidat, S., Baltensperger, U., Haddad, I. E., and Prévôt, A. S. H.: High secondary aerosol contribution to particulate pollution during haze events in China, Nature, 514, 218, 
https://doi.org/10.1038/nature13774, 2014.

Ibusuki, T., and Takeuchi, K.: Sulfur dioxide oxidation by oxygen catalyzed by mixtures of manganese

(II) and iron (III) in aqueous solutions at environmental reaction conditions, Atmos. Environ, 21, 1555-1560, http://dx.doi.org/10.1016/0004-6981(87)90317-9, 1987.

Ji, D., Li, L., Wang, Y., Zhang, J., Cheng, M., Sun, Y., Liu, Z., Wang, L., Tang, G., Hu, B., Chao, N., Wen, T., and Miao, H.: The heaviest particulate air-pollution episodes occurred in northern China in January, 2013: Insights gained from observation, Atmos. Environ, 92, 546-556, http://dx.doi.org/10.1016/j.atmosenv.2014.04.048, 2014.

Kong, L., Du, C., Zhanzakova, A., Cheng, T., Yang, X., Wang, L., Fu, H., Chen, J., and Zhang, S.: Trends in heterogeneous aqueous reaction in continuous haze episodes in suburban Shanghai: An in-depth case study, Sci. Total. Environ, 634, 1192-1204, http://dx.doi.org/10.1016/j.scitotenv.2018.04.086, 2018.

Kong, L. D., Zhao, X., Sun, Z. Y., Yang, Y. W., Fu, H. B., Zhang, S. C., Cheng, T. T., Yang, X., Wang, L., and M., C. J.: The effects of nitrate on the heterogeneous uptake of sulfur dioxide on hematite, Atmos. Chem. Phys., 14, 9451-9467, http://dx.doi.org/10.5194/acp-14-9451-2014, 2014.

Li, L., Huang, C., Huang, H., Wang, Y., Yan, R., Zhang, G., Zhou, M., Lou, S., Tao, S., and Wang, H. J. A. e.: An integrated process rate analysis of a regional fine particulate matter episode over Yangtze River Delta in 2010, Atmos. Environ, 91, 60-70, http://dx.doi.org/10.1016/j.atmosenv.2014.03.053, 2014.

Li, L., Duan, Z., Li, H., Zhu, C., Henkelman, G., Francisco, J. S., and Zeng, X. C.: Formation of HONO from the $\mathrm{NH}_{3}$-promoted hydrolysis of $\mathrm{NO}_{2}$ dimers in the atmosphere, Proc. Natl. Acad. Sci. USA, 115, 7236-7241, http://dx.doi.org/10.1073/pnas.1807719115, 2018a.

Li, L., Hoffmann, M. R., and Colussi, A. J.: Role of nitrogen dioxide in the production of sulfate during Chinese haze-aerosol episodes, Environ. Sci. Technol, 52, 2686-2693, http://dx.doi.org/10.1021/acs.est.7b05222, 2018b.

Liu, M., Song, Y., Zhou, T., Xu, Z., Yan, C., Zheng, M., Wu, Z., Hu, M., Wu, Y., and Zhu, T.: Fine particle $\mathrm{pH}$ during severe haze episodes in northern China, Geophys. Res. Lett, 44, 5213-5221, http://dx.doi.org/10.1002/2017g1073210, 2017a.

Liu, Y., Wu, Z., Wang, Y., Xiao, Y., Gu, F., Zheng, J., Tan, T., Shang, D., Wu, Y., Zeng, L., Hu, M., P. Bateman, A., and Martin, S.: Submicrometer particles are in the liquid state during heavy haze episodes in the urban atmosphere of Beijing, China, Environ. Sci. Technol. Lett, 4, http://dx.doi.org/10.1021/acs.estlett.7b00352, 2017b.

Lu, K., Fuchs, H., Hofzumahaus, A., Tan, Z., Wang, H., Zhang, L., Schmitt, S. H., Rohrer, F., Bohn, B., Broch, S., Dong, H., Gkatzelis, G. I., Hohaus, T., Holland, F., Li, X., Liu, Y., Liu, Y., Ma, X., Novelli, A., Schlag, P., Shao, M., Wu, Y., Wu, Z., Zeng, L., Hu, M., Kiendler-Scharr, A., Wahner, A., and Zhang, Y.: Fast photochemistry in wintertime haze: Consequences for pollution mitigation strategies, Environ. Sci. Technol, 53, 10676-10684, http://dx.doi.org/10.1021/acs.est.9b02422, 2019.

Mack, J., and Bolton, J. R.: Photochemistry of nitrite and nitrate in aqueous solution: a review, J. Photochem. Photobio. A, 128, 1-13, https://doi.org/10.1016/S1010-6030(99)00155-0, 1999.

Mark, G., Korth, H.G., Schuchmann, H.P., and von Sonntag, C.: The photochemistry of aqueous nitrate ion revisited, J. Photochem. Photobio. A, 101, 89-103, https://doi.org/10.1016/S10106030(96)04391-2, 1996.

Mozurkewich, M.: Mechanisms for the release of halogens from sea-salt particles by free radical reactions, J. Geophys. Res, 100, 14199-14207, http://dx.doi.org/10.1029/94JD00358, 1995. 
Niu, J., Li, Y., and Wang, W.: Light-source-dependent role of nitrate and humic acid in tetracycline photolysis: kinetics and mechanism, Chemosphere, 92, 1423-1429, http://dx.doi.org/10.1016/j.chemosphere.2013.03.049, 2013.

Quan, J., Liu, Q., Li, X., Gao, Y., Jia, X., Sheng, J., and Liu, Y.: Effect of heterogeneous aqueous reactions on the secondary formation of inorganic aerosols during haze events, Atmos. Environ, 122, 306-312, http://dx.doi.org/10.1016/j.atmosenv.2015.09.068, 2015.

Richards-Henderson, N. K., Callahan, K. M., Nissenson, P., Nishino, N., Tobias, D. J., and FinlaysonPitts, B. J.: Production of gas phase $\mathrm{NO}_{2}$ and halogens from the photolysis of thin water films containing nitrate, chloride and bromide ions at room temperature, Phys. Chem. Chem. Phys, 15, 17636-17646, http://dx.doi.org/10.1039/C3CP52956H, 2013.

Richards, N. K., Wingen, L. M., Callahan, K. M., Nishino, N., Kleinman, M. T., Tobias, D. J., and Finlayson-Pitts, B. J.: Nitrate ion photolysis in thin water films in the presence of bromide ions, J. Phys. Chem. A, 115, 5810-5821, http://dx.doi.org/10.1021/jp109560j, 2011.

Richards, N. K., and Finlayson-Pitts, B. J.: Production of gas phase $\mathrm{NO}_{2}$ and halogens from the photochemical oxidation of aqueous mixtures of sea salt and nitrate ions at room temperature, Environ. Sci. Technol, 46, 10447-10454, http://dx.doi.org/10.1021/es300607c, 2012.

Scharko, N. K., Berke, A. E., and Raff, J. D.: Release of nitrous acid and nitrogen dioxide from nitrate photolysis in acidic aqueous solutions, Environ. Sci. Technol, 48, 11991-12001, http://dx.doi.org/10.1021/es503088x, 2014.

Seinfeld, J., and Pandis, S.: Atmospheric chemistry and physics: from air pollution to climate change, John. Wiley. Sons, New York, 2006.

Shen, X., Lee, T., Guo, J., Wang, X., Li, P., Xu, P., Wang, Y., Ren, Y., Wang, W., Wang, T., Li, Y., Carn, S. A., and Collett, J. L.: Aqueous phase sulfate production in clouds in eastern China, Atmos. Environ, 62, 502-511, https://doi.org/10.1016/j.atmosenv.2012.07.079, 2012.

Shuali, U., Ottolenghi, M., Rabani, J., and Yelin, Z.: Photochemistry of aqueous nitrate solutions excited in the 195-nm band, J. Phys. Chem, 73, 3445-3451, https://doi.org/10.1021/j100844a052, 1969.

Sun, Y., Jiang, Q., Wang, Z., Fu, P., Li, J., Yang, T., and Yin, Y.: Investigation of the sources and evolution processes of severe haze pollution in Beijing in January 2013, J. Geophys. Res. Atmos, 119, 43804398, https://doi.org/10.1002/2014JD021641, 2014.

Sun, Y. L., Wang, Z. F., Fu, P. Q., Yang, T., Jiang, Q., Dong, H. B., Li, J., and Jia, J. J.: Aerosol composition, sources and processes during wintertime in Beijing, China, Atmos. Chem. Phys., 13, 4577-4592, https://doi.org/10.5194/acp-13-4577-2013, 2013.

Tan, Z., Rohrer, F., Lu, K., Ma, X., Bohn, B., Broch, S., Dong, H., Fuchs, H., Gkatzelis, G. I., Hofzumahaus, A., Holland, F., Li, X., Liu, Y., Liu, Y. H., Novelli, A., Shao, M., Wang, H. C., Wu, Y. S., Zeng, L. M., H, M., Kiendler-Scharr, A., Wahner, A., and Zhang, Y. H.: Wintertime photochemistry in Beijing: observations of $\mathrm{RO}_{\mathrm{x}}$ radical concentrations in the North China Plain during the BEST-ONE campaign, Atmos. Chem. Phys., 18, 12391-12411, https://doi.org/10.5194/acp-18-12391-2018, 2018.

Tao, J., Zhang, Z., Tan, H., Zhang, L., Wu, Y., Sun, J., Che, H., Cao, J., Cheng, P., Chen, L., and Zhang, R.: Observational evidence of cloud processes contributing to daytime elevated nitrate in an urban atmosphere, Atmos. Environ, 186, 209-215, https://doi.org/10.1016/j.atmosenv.2018.05.040, 2018.

Tong, S. Y., Kong, L. D., Yang, K. J., Shen, J. D., Chen, L., Jin, S. Y., Wang, C., Sha, F., Wang, L.: Characteristics of air pollution episodes influenced by biomass burning pollution in Shanghai, China, Atmos. Environ, 117756, https://doi.org/10.1016/j.atmosenv.2020.117756, 2020. 
Troian-Gautier, L., Turlington, M. D., Wehlin, S. A. M., Maurer, A. B., Brady, M. D., Swords, W. B., and Meyer, G. J.: Halide photoredox chemistry, Chem. Rev, 119, 4628-4683, https://doi.org/10.1021/acs.chemrev.8b00732, 2019.

Turnipseed, A. A., Vaghjiani, G. L., Thompson, J. E., and Ravishankara, A. R.: Photodissociation of $\mathrm{HNO}_{3}$ at 193, 222, and $248 \mathrm{~nm}$ : Products and quantum yields, J. Chem. Phys, 96, 5887-5895, https://doi.org/10.1063/1.462685, 1992.

Vogt, R., Crutzen, P. J., and Sander, R.: A mechanism for halogen release from sea-salt aerosol in the remote marine boundary layer, Nature, 383, 327, http://dx.doi.org/10.1038/383327a0, 1996.

Wagner, I., Strehlow, H., and Busse, G.: Flash photolysis of nitrate ions in aqueous solution, J. Chem. Soc. A, 123, 1-33, http://dx.doi.org/10.1524/zpch.1980.123.1.001, 1980.

Wang, G., Zhang, R., Gomez, M. E., Yang, L., Zamora, M. L., Hu, M., Lin, Y., Peng, J., Guo, S., Meng, J., Li, J., Cheng, C., Hu, T., Ren, Y., Wang, Y., Gao, J., Cao, J., An, Z., Zhou, W., Li, G., Wang, J., Tian, P., Marrero-Ortiz, W., Secrest, J., Du, Z., Zheng, J., Shang, D., Zeng, L., Shao, M., Wang, W., Huang, Y., Wang, Y., Zhu, Y., Li, Y., Hu, J., Pan, B., Cai, L., Cheng, Y., Ji, Y., Zhang, F., Rosenfeld, D., Liss, P. S., Duce, R. A., Kolb, C. E., Molina. M. J.: Persistent sulfate formation from London fog to Chinese haze, Proc. Natl. Acad. Sci. USA, 113, 13630-13635, http://dx.doi.org/10.1073/pnas.1616540113, 2016.

Wingen, L. M., Moskun, A. C., Johnson, S. N., Thomas, J. L., Roeselova, M., Tobias, D. J., Kleinman, M. T., and Finlayson-Pitts, B. J.: Enhanced surface photochemistry in chloride-nitrate ion mixtures, Phys. Chem. Chem. Phys, 10, 5668-5677, http://dx.doi.org/10.1039/b806613b, 2008.

Xia, S.S., Eugene, A. J., and Guzman, M. I.: Cross photoreaction of glyoxylic and pyruvic acids in model aqueous aerosol, J. Phys. Chem. A, 122, 6457-6466, http://dx.doi.org/10.1021/acs.jpca.8b05724, 2018.

Xu, W., Kuang, Y., Zhao, C., Tao, J., Zhao, G., Bian, Y., Yang, W., Yu, Y., Shen, C., Liang, L., Zhang, G., Lin, W., and $\mathrm{Xu}, \mathrm{X} .: \mathrm{NH}_{3}$-promoted hydrolysis of $\mathrm{NO}_{2}$ induces explosive growth in $\mathrm{HONO}$, Atmos. Chem. Phys, 19, 10557-10570, http://dx.doi.org/10.5194/acp-19-10557-2019, 2019.

Yabushita, A., Iida, D., Hama, T., and Kawasaki, M.: Direct observation of OH radicals ejected from water ice surface in the photoirradiation of nitrate adsorbed on ice at $100 \mathrm{~K}$, J. Phys. Chem. A, 112, 9763-9766, http://dx.doi.org/10.1021/jp804622z, 2008.

Ye, C., Gao, H., Zhang, N., and Zhou, X.: Photolysis of nitric acid and nitrate on natural and artificial surfaces, Environ. Sci. Technol, 50, 3530-3536, http://dx.doi.org/10.1021/acs.est.5b05032, 2016.

Ye, C., Liu, P., Ma, Z., Xue, C., Zhang, C., Zhang, Y., Liu, J., Liu, C., Sun, X., and Mu, Y.: High $\mathrm{H}_{2} \mathrm{O}_{2}$ concentrations observed during haze periods during the winter in Beijing: Importance of $\mathrm{H}_{2} \mathrm{O}_{2}$ oxidation in sulfate formation, Environ. Sci. Technol. Lett, 5, 757-763, http://dx.doi.org/10.1021/acs.estlett.8b00579, 2018.

Zhang, K., and Parker, K. M.: Halogen radical oxidants in natural and engineered aquatic systems, Environ. Sci. Technol, 52, 9579-9594, http://dx.doi.org/10.1021/acs.est.8b02219, 2018.

Zheng, B., Zhang, Q., Zhang, Y., He, K. B., Wang, K., Zheng, G. J., Duan, F. K., Ma, Y. L., and Kimoto, T.: Heterogeneous chemistry: a mechanism missing in current models to explain secondary inorganic aerosol formation during the January 2013 haze episode in North China, Atmos. Chem. Phys, 14, 2031-2049, http://dx.doi.org/10.5194/acp-15-2031-2015, 2015a.

Zheng, G., K. Duan, F., Su, H., L. Ma, Y., Cheng, Y., Zheng, B., Zhang, Q., Huang, T., Kimoto, T., Chang, D., Pöschl, U., Cheng, Y., and B. He, K.: Exploring the severe winter haze in Beijing: The impact of synoptic weather, regional transport and heterogeneous reactions, Atmos. Chem. Phys, 15, 2969- 


\section{Figure Captions}

Figure 1. Sulfate formation in the presence and absence of nitrate photolysis and $\mathrm{O}_{2}$ under (a) solar irradiation and (b) $313 \mathrm{~nm}$ UV light. The concentrations of $\mathrm{NaHSO}_{3}$ and the added $\mathrm{NH}_{4} \mathrm{NO}_{3}$ were both $30 \mathrm{mM}$. The light intensity was $8 \mathrm{~mW} / \mathrm{cm}^{2}$.

Figure 2. Generation of $\mathrm{NO}_{\mathrm{x}}$ during nitrate photolysis under $313 \mathrm{~nm} \mathrm{UV} \mathrm{light.}$

Figure 3. Sulfate formation at different $\mathrm{pH}$ values adjusted by the addition of $\left(\mathrm{NH}_{4}\right)_{2} \mathrm{SO}_{4}$ (AS), $\mathrm{NH}_{4} \mathrm{HSO}_{4}(\mathrm{ABS})$ and the mixture of $\left(\mathrm{NH}_{4}\right)_{2} \mathrm{SO}_{4}$ and $\mathrm{NH}_{4} \mathrm{HSO}_{4}$, respectively. Reaction conditions: $30 \mathrm{mM} \mathrm{NaHSO}, 30 \mathrm{mM} \mathrm{NH}_{4} \mathrm{NO}_{3}$, light $\left(8 \mathrm{~mW} / \mathrm{cm}^{2}\right)$ and air.

Figure 4. Comparison of $\mathrm{NH}_{4} \mathrm{NO}_{3}$ and $\mathrm{NaNO}_{3}$ as the source of $\mathrm{NO}_{3}^{-}$for sulfate formation at different $\mathrm{pH}$. Reaction conditions: $30 \mathrm{mM} \mathrm{NaHSO}_{3}, 30 \mathrm{mM} \mathrm{NH}_{4} \mathrm{NO}_{3}$ or $\mathrm{NaNO}_{3}$, light $\left(8 \mathrm{~mW} / \mathrm{cm}^{2}\right)$ and air.

Figure 5. Inhibition of 2-propanol on aqueous phase oxidation of bisulfite. Reaction conditions: $30 \mathrm{mM} \mathrm{NaHSO}_{3}, 30 \mathrm{mM} \mathrm{NH}_{4} \mathrm{NO}_{3}, 20 \mathrm{mM}$ 2-propanol, light $\left(8 \mathrm{~mW} / \mathrm{cm}^{2}\right)$ and air.

Figure 6. $\mathrm{H}_{2} \mathrm{O}_{2}$ produced during the photochemical reaction of nitrate under $313 \mathrm{~nm}$ irradiation.

Figure 7. (a) Effects of halide ions on aqueous phase oxidation of bisulfite under light and (b) comparison of the effects of halide ions under dark and light conditions. Reaction conditions: 30 mM NaHSO 3,30 mM NH $4 \mathrm{NO}_{3}, 30 \mathrm{mM} \mathrm{NaCl}, \mathrm{NaBr}$ and $\mathrm{NaI}$, respectively, light $\left(8 \mathrm{~mW} / \mathrm{cm}^{2}\right)$ and air.

\section{Tables}

Table 1. $\cdot \mathrm{OH}$ quantum yields of nitrate photolysis as a function of $\mathrm{pH}$.

Table 2. Reactions and their rate constants or quantum yields involved in this study. 

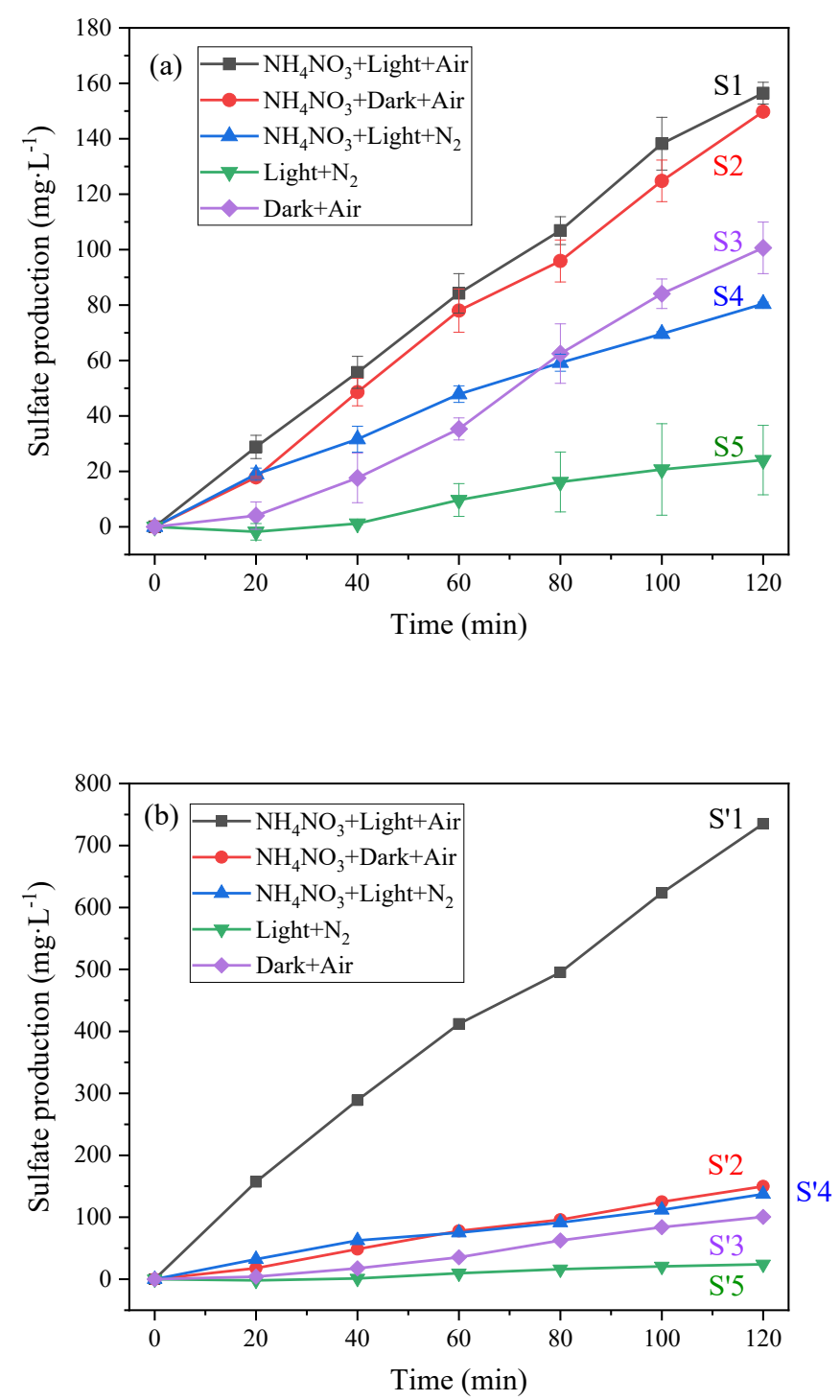

753 Figure 1. Sulfate formation in the presence and absence of nitrate photolysis and $\mathrm{O}_{2}$

755 the added $\mathrm{NH}_{4} \mathrm{NO}_{3}$ were both $30 \mathrm{mM}$. The light intensity was $8 \mathrm{~mW} / \mathrm{cm}^{2}$. 
https://doi.org/10.5194/acp-2020-806

Preprint. Discussion started: 31 August 2020

(C) Author(s) 2020. CC BY 4.0 License. \begin{tabular}{l} 
Atmospheric $\stackrel{0}{\circ}$ \\
Chemistry \\
and Physics \\
\hline Discussions
\end{tabular}

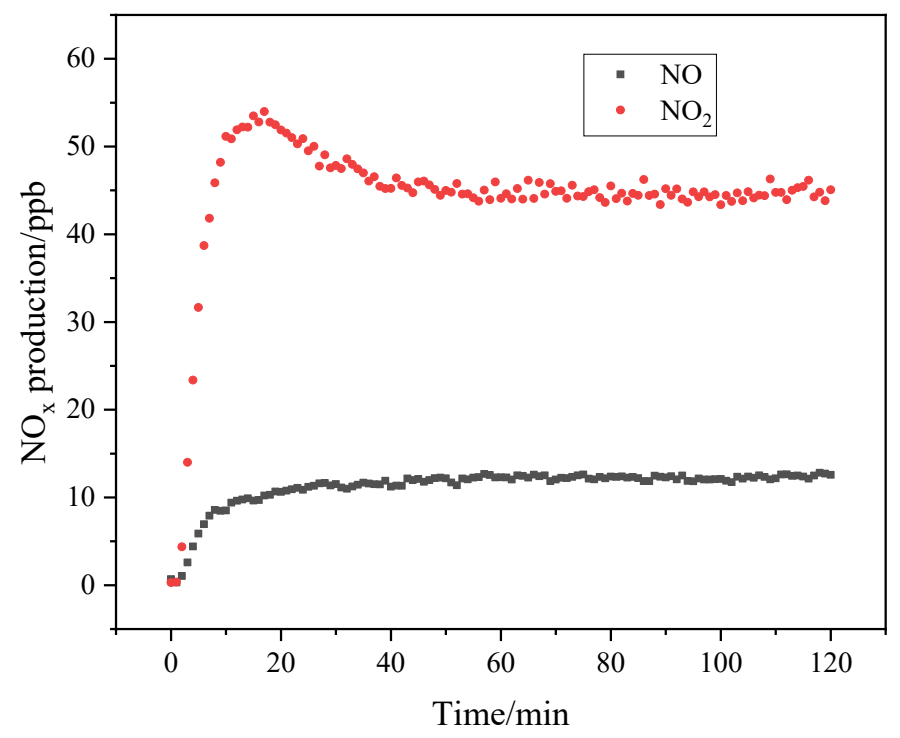

756

757 Figure 2. Generation of $\mathrm{NO}_{\mathrm{x}}$ during nitrate photolysis under $313 \mathrm{~nm}$ UV light. 

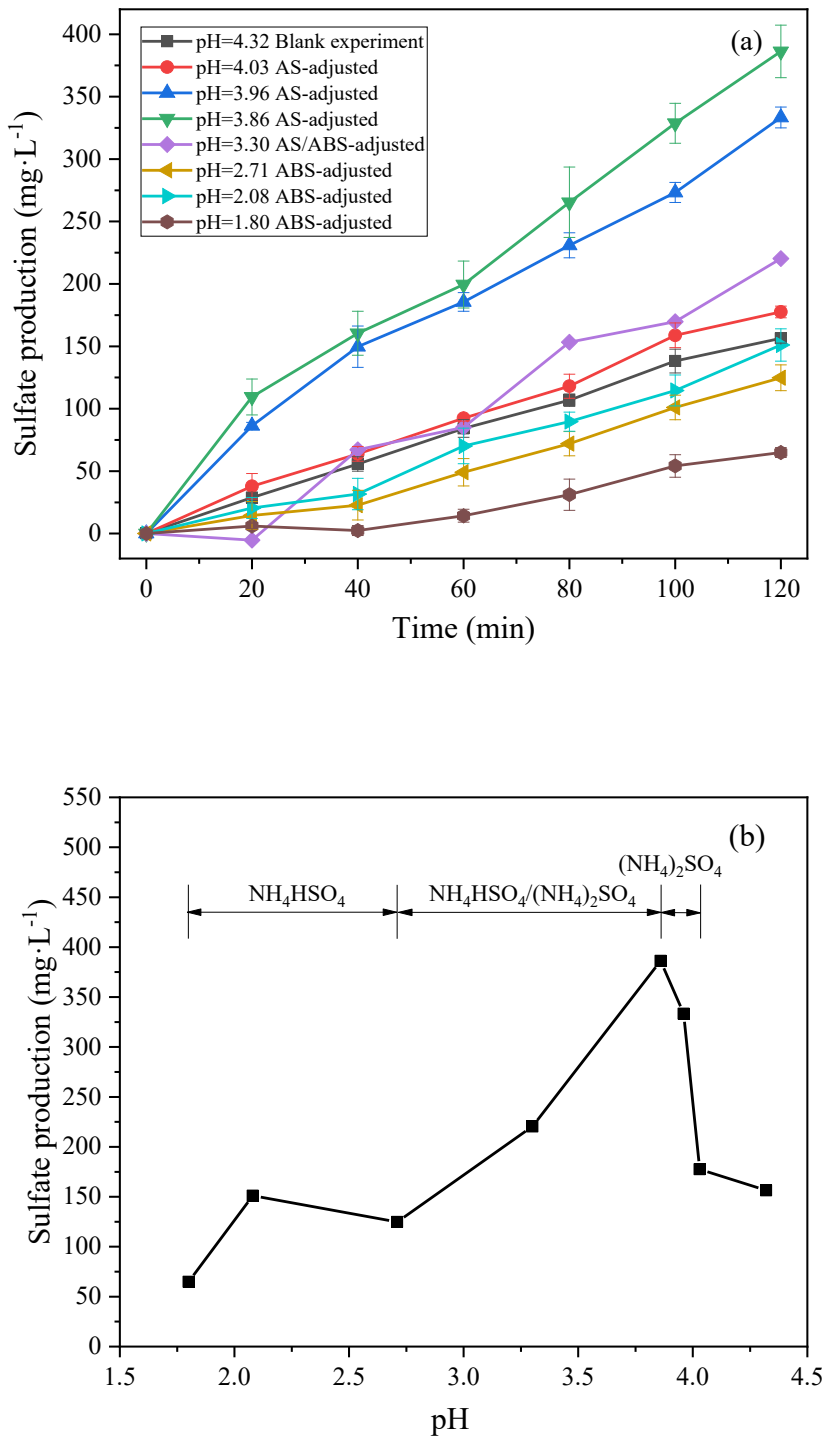

759

760 Figure 3. Sulfate formation at different $\mathrm{pH}$ values adjusted by the addition of $\left(\mathrm{NH}_{4}\right)_{2} \mathrm{SO}_{4}$

761 (AS), $\mathrm{NH}_{4} \mathrm{HSO}_{4}$ (ABS) and the mixture of $\left(\mathrm{NH}_{4}\right)_{2} \mathrm{SO}_{4}$ and $\mathrm{NH}_{4} \mathrm{HSO}_{4}$, respectively.

Reaction conditions: $30 \mathrm{mM} \mathrm{NaHSO}$, $30 \mathrm{mM} \mathrm{NH}_{4} \mathrm{NO}_{3}$, light $\left(8 \mathrm{~mW} / \mathrm{cm}^{2}\right)$ and air. 


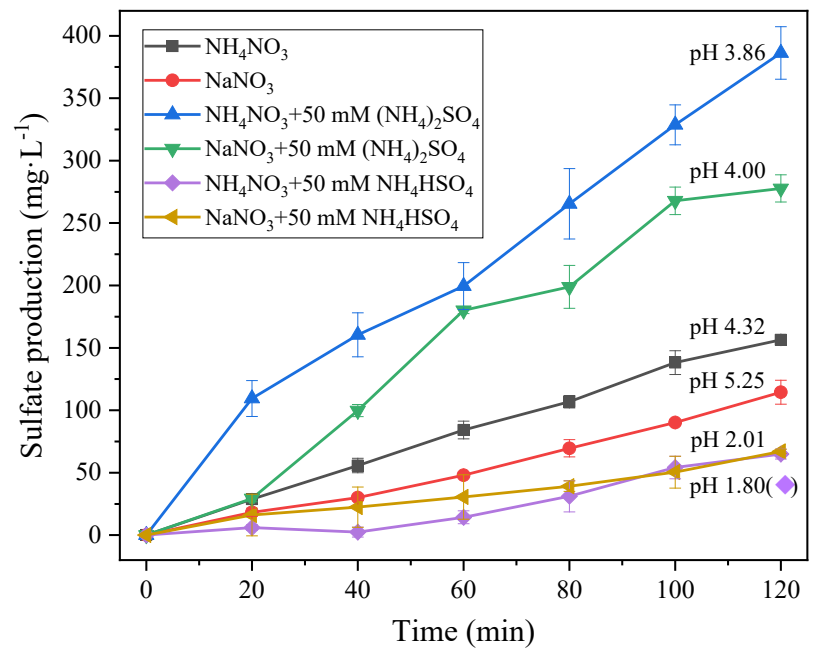

765

766 Figure 4. Comparison of $\mathrm{NH}_{4} \mathrm{NO}_{3}$ and $\mathrm{NaNO}_{3}$ as the source of $\mathrm{NO}_{3}^{-}$for sulfate

767 formation at different $\mathrm{pH}$. Reaction conditions: $30 \mathrm{mM} \mathrm{NaHSO} 3,30 \mathrm{mM} \mathrm{NH} 4 \mathrm{NO}_{3}$ or

$\mathrm{NaNO}_{3}$, light $\left(8 \mathrm{~mW} / \mathrm{cm}^{2}\right)$ and air.

769

770

771

772 


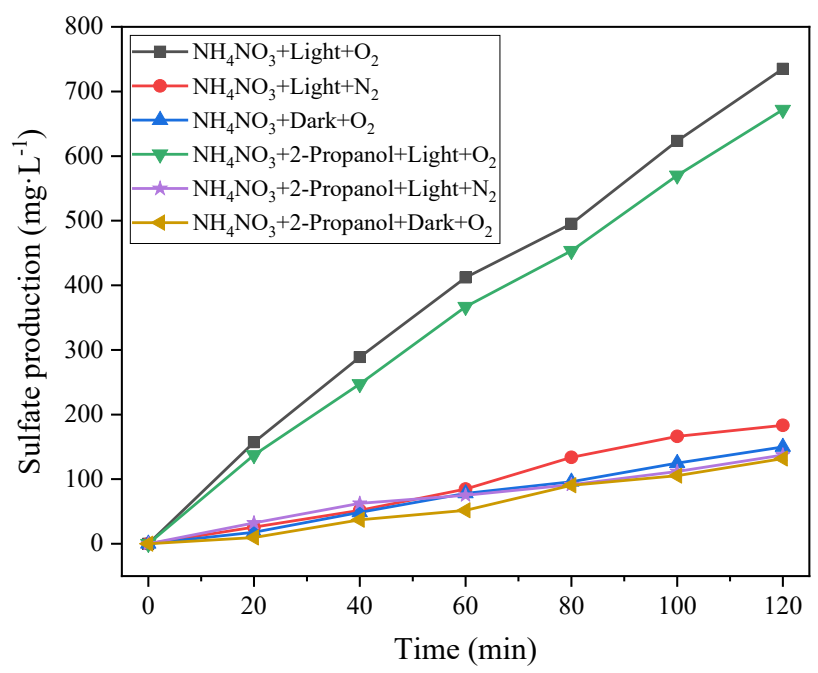

779

780 Figure 5. Inhibition of 2-propanol on aqueous phase oxidation of bisulfite under 313 


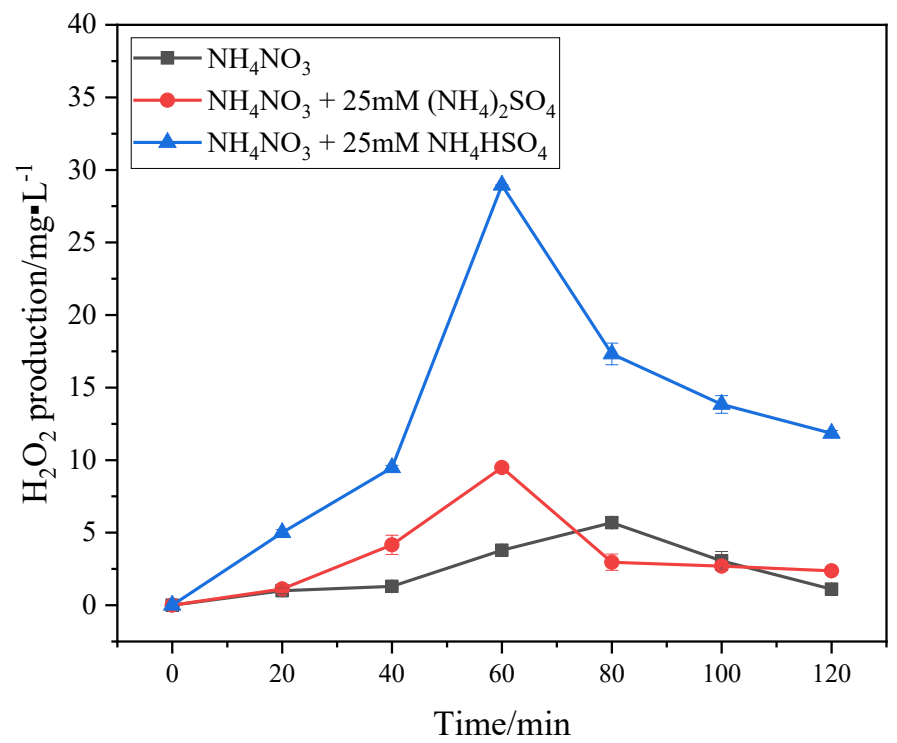

784

785 Figure 6. $\mathrm{H}_{2} \mathrm{O}_{2}$ produced during the photochemical reaction of nitrate under $313 \mathrm{~nm}$ 

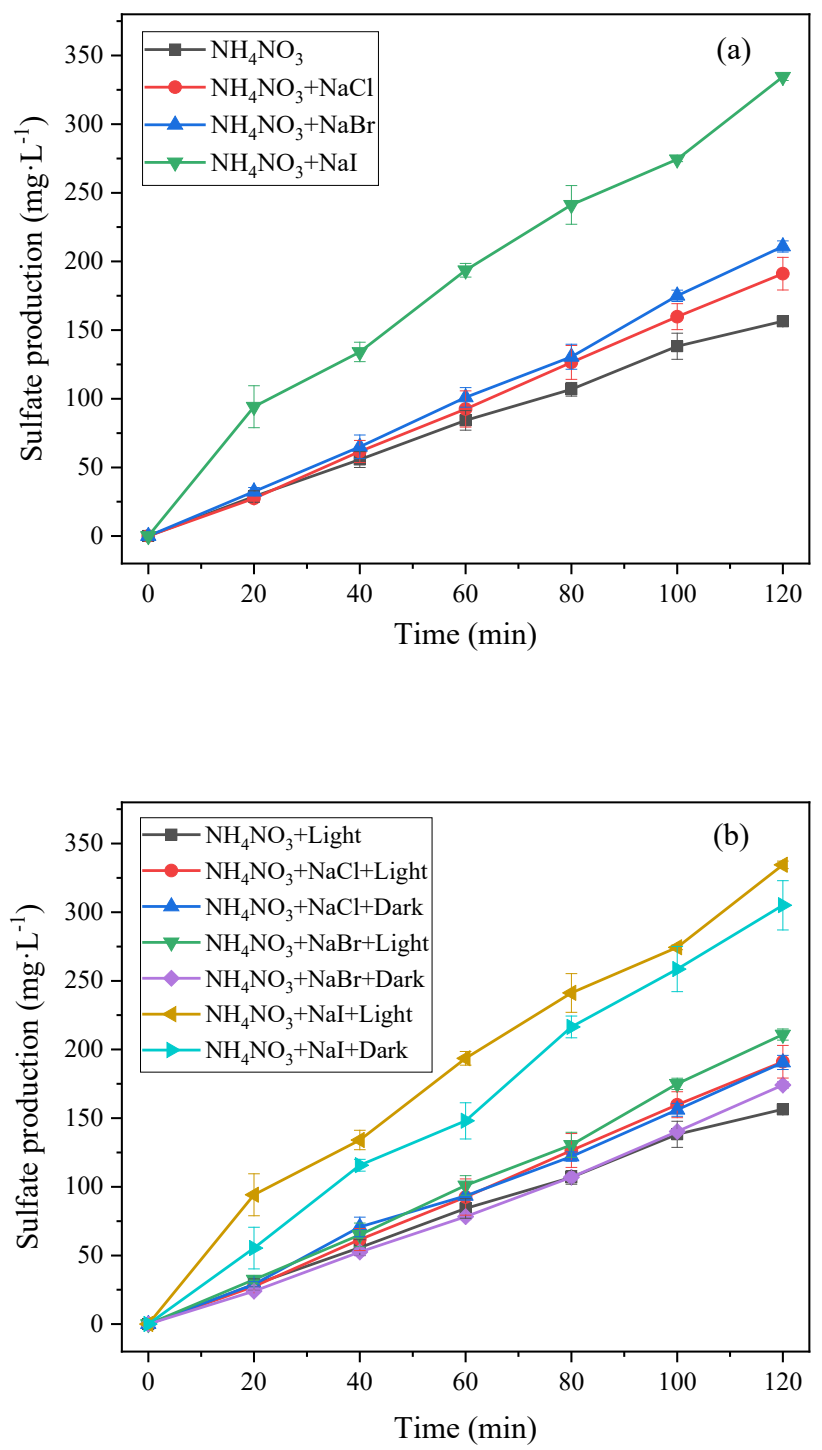

790 Figure 7. (a) Effects of halide ions on aqueous phase oxidation of bisulfite under light

791 and (b) comparison of the effects of halide ions under dark and light conditions.

792 Reaction conditions: $30 \mathrm{mM} \mathrm{NaHSO}_{3}, 30 \mathrm{mM} \mathrm{NH}_{4} \mathrm{NO}_{3}, 30 \mathrm{mM} \mathrm{NaCl}, \mathrm{NaBr}$ and $\mathrm{NaI}$, respectively, light $\left(8 \mathrm{~mW} / \mathrm{cm}^{2}\right)$ and air. 
https://doi.org/10.5194/acp-2020-806

Preprint. Discussion started: 31 August 2020

(c) Author(s) 2020. CC BY 4.0 License.

800

801

Table 1. $\bullet \mathrm{OH}$ quantum yields of nitrate photolysis as a function of $\mathrm{pH}$.

\begin{tabular}{ccc}
\hline Conditions & $\mathrm{pH}$ & $\Phi \cdot \mathrm{OH}\left(\times 10^{-3}\right)$ \\
\hline Air & 4.32 & $4.240 \pm 0.353$ \\
Air & 4.03 & $4.033 \pm 0.525$ \\
Air & 3.96 & $7.785 \pm 0.490$ \\
Air & 2.71 & $8.252 \pm 0.226$ \\
Air & 2.08 & $16.672 \pm 0.899$ \\
\hline
\end{tabular}

802 
https://doi.org/10.5194/acp-2020-806

Preprint. Discussion started: 31 August 2020

(c) Author(s) 2020. CC BY 4.0 License.

803 Table 2. Reactions and their rate constants or quantum yields involved in this study.

\begin{tabular}{|c|c|c|c|}
\hline No. & Reaction & $k$ or $\Phi$ & Ref \\
\hline R1 & $\mathrm{SO}_{2(\mathrm{~g})} \stackrel{k_{1}}{\Leftrightarrow} \mathrm{SO}_{2} \cdot \mathrm{H}_{2} \mathrm{O} \stackrel{k_{2}}{\Leftrightarrow} \mathrm{HSO}_{3}^{-}+\mathrm{H}^{+} \stackrel{k_{3}}{\Leftrightarrow} \mathrm{SO}_{3}^{2-}+2 \mathrm{H}^{+}$ & $k_{1}=1.23 ; k_{2}=1.3 \times 10^{-2} ; k_{3}=6.6 \times 10^{-8}$ & (Alexander et al., 2003;Gen et al., 2019b) \\
\hline R2 & $\mathrm{HSO}_{3}^{-}+\mathrm{H}_{2} \mathrm{O}_{2} \rightarrow \mathrm{HSO}_{4}^{-}+\mathrm{H}_{2} \mathrm{O}$ & $k=7.45 \times 10^{7} \mathrm{M}^{-1} \mathrm{~s}^{-1}$ & (Seinfeld and Pandis, 2006;Ye et al., 2018;Shen et al., 2012) \\
\hline R3 & $\mathrm{NO}_{3}^{-}+h v\left(+\mathrm{H}^{+}\right) \rightarrow \mathrm{NO}_{2}+\cdot \mathrm{OH}$ & $k=8.5 \times 10^{-7} \mathrm{~s}^{-1} ; \Phi(\lambda=305 \mathrm{~nm})=(9.2 \pm 0.4) \times 10^{-3}$ & (Scharko et al., 2014;Yabushita et al., 2008) \\
\hline R4 & $\mathrm{NO}_{3}^{-}+h v \rightarrow \mathrm{NO}_{2}+\mathrm{O}^{-}$ & $\Phi(\lambda>290 \mathrm{~nm})=0.01$ & (Scharko et al., 2014) \\
\hline R5 & $\mathrm{NO}_{3}^{-}+h v \rightarrow \mathrm{NO}_{2}^{-}+\mathrm{O}\left({ }^{3} \mathrm{P}\right)$ & $k=8.5 \times 10^{-8} \mathrm{~s}^{-1} ; \Phi(\lambda=305 \mathrm{~nm})=0.001$ & (Scharko et al., 2014) \\
\hline R6 & $2 \mathrm{NO}_{2}+\mathrm{H}_{2} \mathrm{O} \rightarrow \mathrm{HONO}+\mathrm{H}^{+}+\mathrm{NO}_{3}^{-}$ & $k=1 \times 10^{8}$ & (Li et al., 2018b;Richards-Henderson et al., 2013) \\
\hline R7 & $2 \mathrm{NO}_{2}+\mathrm{H}_{2} \mathrm{O}+h v \rightarrow \mathrm{HONO}+\cdot \mathrm{OH}$ & $k=1.7 \times 10^{-10} \mathrm{~cm}^{3} \mathrm{~mol}^{-1} \mathrm{~s}^{-1}$ & (Bao et al., 2018;Gligorovski et al., 2015) \\
\hline R8 & $\mathrm{NO}_{2}^{-}+\mathrm{H}_{2} \mathrm{O} \rightarrow \mathrm{HONO}+\mathrm{OH}^{-}$ & - & (Yabushita et al., 2008) \\
\hline R9 & $\mathrm{O}^{-}+\mathrm{H}^{+} / \mathrm{H}_{3} \mathrm{O}^{+} \rightarrow \cdot \mathrm{OH}+\mathrm{H}_{2} \mathrm{O}$ & - & (Yabushita et al., 2008) \\
\hline R10 & $\mathrm{HONO}\left(\right.$ or $\left.\mathrm{NO}_{2}^{-}+\mathrm{H}^{+}\right)+h v \rightarrow \cdot \mathrm{OH}+\cdot \mathrm{NO}$ & $k=1.0 \times 10^{-3} \mathrm{~s}^{-1} ; \Phi(\lambda<390 \mathrm{~nm})=1.0$ & (Li et al., 2018b;Scharko et al., 2014) \\
\hline R11 & $\mathrm{NO}_{2}+\mathrm{HSO}_{3}^{-}+\mathrm{H}_{2} \mathrm{O} \rightarrow 3 \mathrm{H}^{+}+2 \mathrm{NO}_{2}^{-}+\mathrm{SO}_{4}^{2-}$ & - & (Clifton et al., 1988) \\
\hline R12 & $\mathrm{NO}_{2}+\mathrm{HSO}_{3}^{-}+\mathrm{H}_{2} \mathrm{O}+\mathrm{O}_{2} \rightarrow \mathrm{H}^{+}+\mathrm{NO}_{3}^{-}+\cdot \mathrm{OH}+\mathrm{HSO}_{4}^{-}$ & - & (Li et al., 2018b) \\
\hline R13 & $\mathrm{NO}_{2}+h v \rightarrow \mathrm{NO}+\mathrm{O}$ & $k=1.1 \times 10^{-2} \mathrm{~s}^{-1}$ & (Scharko et al., 2014) \\
\hline R14 & $\mathrm{HONO}+h v \rightarrow \mathrm{NO}+\mathrm{OH}$ & $k=1.0 \times 10^{-3} \mathrm{~s}^{-1}$ & (Scharko et al., 2014) \\
\hline R15 & $\cdot \mathrm{OH}+\mathrm{H}_{2} \mathrm{O}_{2} \rightarrow \mathrm{H}_{2} \mathrm{O}+\cdot \mathrm{HO}_{2}$ & $k=2.7 \times 10^{7} \mathrm{M}^{-1} \mathrm{~s}^{-1}$ & (Hislop and Bolton, 1999;Gligorovski et al., 2015) \\
\hline R16 & $\mathrm{O}\left({ }^{3} \mathrm{P}\right)+\mathrm{O}_{2} \rightarrow \mathrm{O}_{3}$ & $k=4 \times 10^{9} \mathrm{M}^{-1} \mathrm{~s}^{-1}$ & (Dubowski et al., 2001;Herrmann, 2007) \\
\hline R17 & $\mathrm{X}^{-}+h v \rightarrow \mathrm{X}^{*}+\mathrm{e}^{-}$ & - & (Zhang and Parker, 2018) \\
\hline R18 & $\mathrm{X}^{*}+\mathrm{X}^{-}\left(\right.$or $\left.\mathrm{Y}^{-}\right) \rightleftharpoons \mathrm{X}^{*^{-}}\left(\right.$or $\left.\mathrm{XY}^{*-}\right)$ & $k=8.5 \times 10^{9}(\mathrm{Cl}) / 1.6-2.8 \times 10^{9}(\mathrm{Br}) / 0.1-1.2 \times 10^{10}(\mathrm{I}) \mathrm{M}^{-1} \mathrm{~s}^{-1}$ & (Zhang and Parker, 2018;Troian-Gautier et al., 2019) \\
\hline R19 & ${ }^{\circ} \mathrm{OH}+\mathrm{X}^{-} \rightleftharpoons \mathrm{HOX}^{-} \rightleftharpoons \mathrm{OH}^{-}+\mathrm{X}^{\cdot}$ & - & (Zhang and Parker, 2018) \\
\hline
\end{tabular}

804

805

806

807

808

809

810 
https://doi.org/10.5194/acp-2020-806

Preprint. Discussion started: 31 August 2020

(c) Author(s) 2020. CC BY 4.0 License.

818 Table 2. Reactions and their rate constants or quantum yields involved in this study

819 (continued).

\begin{tabular}{|c|c|c|c|}
\hline No. & Reaction & $k$ or $\Phi$ & Ref \\
\hline R20 & $\mathrm{HOX}^{*-+}+\mathrm{H}^{+} \rightleftharpoons \mathrm{H}_{2} \mathrm{O}+\mathrm{X}^{*}$ & - & (Zhang and Parker, 2018) \\
\hline R21 & $\mathrm{HOX}^{*-}+\mathrm{X}^{-}$(or $\left.\mathrm{Y}^{-}\right) \rightleftharpoons \mathrm{OH}^{-}+\mathrm{X}_{2^{--}}$(or $\mathrm{XY}^{-}$) & - & (Zhang and Parker, 2018) \\
\hline R22 & $\mathrm{SO}_{4}^{--}+\mathrm{X}^{-} \rightarrow \mathrm{SO}_{4}^{2-}+\mathrm{X}^{\cdot}$ & - & (Zhang and Parker, 2018) \\
\hline R23 & $\mathrm{HSO}_{5}^{-}+\mathrm{Br}^{-} \rightarrow \mathrm{SO}_{4}^{2-}+\mathrm{HOBr}$ & - & (Mozurkewich, 1995) \\
\hline R24 & $\mathrm{HOX}+h v \rightarrow \mathrm{X}^{*}+{ }^{\circ} \mathrm{OH}$ & - & (Zhang and Parker, 2018) \\
\hline R25 & $\mathrm{X}^{*}+\mathrm{X}^{*}\left(\right.$ or $\left.\mathrm{Y}^{*}\right) \rightarrow \mathrm{X}_{2}($ or $\mathrm{XY})$ & - & (Zhang and Parker, 2018) \\
\hline R26 & $\mathrm{X}^{*}+\mathrm{X}_{2}{ }^{--} \rightarrow \mathrm{X}_{2}+\mathrm{X}^{-}$ & - & (Zhang and Parker, 2018) \\
\hline R27 & $\mathrm{X}_{2^{--}}+\mathrm{X}_{2^{--}} \rightarrow \mathrm{X}_{3}^{-}+\mathrm{X}^{-}\left(\right.$or $\left.\mathrm{X}_{2}+2 \mathrm{X}^{-}\right)$ & $k=1.9-9 \times 10^{9}(\mathrm{Cl}) / 0.9-1.2 \times 10^{10}(\mathrm{Br}) / 3.2-3.9 \times 10^{10}(\mathrm{I}) \mathrm{M}^{-1} \mathrm{~s}^{-1}$ & (Zhang and Parker, 2018;Troian-Gautier et al., 2019) \\
\hline R28 & $\mathrm{X}^{*}+\mathrm{OH} \rightarrow \mathrm{HOX}$ & - & (Zhang and Parker, 2018) \\
\hline R29 & $\mathrm{X}_{2}^{2^{--}+} \mathrm{OH} \rightarrow \mathrm{HOX}+\mathrm{X}^{-}$ & - & (Zhang and Parker, 2018) \\
\hline R30 & $\mathrm{HOBr}+\mathrm{Br}+\mathrm{H}^{+} \rightarrow \mathrm{Br}_{2}+\mathrm{H}_{2} \mathrm{O}$ & $k=1.6 \times 10^{10} \mathrm{~L} \mathrm{~mol}^{-1} \mathrm{~s}^{-1}$ & (Richards-Henderson et al., 2013;Mozurkewich, 1995) \\
\hline R31 & $\mathrm{HOBr}+\mathrm{Cl}^{-}+\mathrm{H}^{+} \rightarrow \mathrm{BrCl}+\mathrm{H}_{2} \mathrm{O}$ & $2.3 \times 10^{10} \mathrm{M}^{-2} \mathrm{~s}^{-2}$ & (Richards and Finlayson-Pitts, 2012;Vogt et al., 1996) \\
\hline R32 & $2^{2} \mathrm{OH}+2 \mathrm{Cl}^{-} \rightarrow \mathrm{Cl}_{2}+2 \mathrm{OH}^{-}$ & - & (Alexander et al., 2003) \\
\hline R33 & $2^{2} \mathrm{OH}+2 \mathrm{Br}^{-} \rightarrow \mathrm{Br}_{2}+2 \mathrm{OH}^{-}$ & - & (Richards-Henderson et al., 2013) \\
\hline $\mathrm{R} 34$ & $2^{2} \mathrm{OH}+\mathrm{Br}^{-}+\mathrm{Cl}^{-} \rightarrow \mathrm{BrCl}+2 \mathrm{OH}^{-}$ & - & (Richards and Finlayson-Pitts, 2012) \\
\hline R35 & $\mathrm{NO}_{3}+3 \mathrm{H}^{+}+2 \mathrm{Br} \rightarrow \mathrm{Br}_{2}+\mathrm{HONO}+\mathrm{H}_{2} \mathrm{O}$ & - & (Richards-Henderson et al., 2013) \\
\hline R36 & $\mathrm{HSO}_{3}+\mathrm{HOX} \rightarrow 2 \mathrm{H}^{+}+\mathrm{X}^{-}+\mathrm{SO}_{4}^{2-}$ & - & this work \\
\hline R37 & $\mathrm{HSO}_{3}^{-}+\mathrm{X}_{2}+\mathrm{H}_{2} \mathrm{O} \rightarrow 3 \mathrm{H}^{+}+2 \mathrm{X}^{-}+\mathrm{SO}_{4}^{2-}$ & - & this work \\
\hline R38 & $\mathrm{HSO}_{3}^{-}+\mathrm{HOCl} \rightarrow \mathrm{SO}_{4}^{-}+2 \mathrm{H}^{+}+\mathrm{Cl}^{-}$ & - & (Vogt et al., 1996) \\
\hline R39 & $\mathrm{HSO}_{3}^{-}+\mathrm{HOBr} \rightarrow \mathrm{SO}_{4}^{-}+2 \mathrm{H}^{+}+\mathrm{Br}$ & - & (Vogt et al., 1996) \\
\hline
\end{tabular}

